\title{
Season Exerts Differential Effects of Ocean Acidification and Warming on Growth and Carbon Metabolism of the Seaweed Fucus vesiculosus in the Western Baltic Sea
}

\section{OPEN ACCESS}

Edited by:

Elvira S. Poloczanska,

Commonwealth Scientific and Industrial Research Organisation, Australia

Reviewed by: Yuri Artioli,

Plymouth Marine Laboratory, UK Olga Lage,

University of Porto, Portugal

*Correspondence:

Angelika Graiff

angelika.graiff@uni-rostock.de

Specialty section:

This article was submitted to Global Change and the Future Ocean,

a section of the journal

Frontiers in Marine Science

Received: 23 July 2015 Accepted: 04 December 2015

Published: 22 December 2015

Citation:

Graiff A, Bartsch I, Ruth W, Wahl M and Karsten $U$ (2015) Season Exerts Differential Effects of Ocean Acidification and Warming on Growth and Carbon Metabolism of the Seaweed Fucus vesiculosus in the Western Baltic Sea.

Front. Mar. Sci. 2:112.

doi: 10.3389/fmars.2015.00112

\begin{abstract}
Angelika Graiff ${ }^{1 *}$, Inka Bartsch ${ }^{2}$, Wolfgang Ruth ${ }^{3}$, Martin Wahl ${ }^{4}$ and Ulf Karsten ${ }^{1}$
${ }^{1}$ Applied Ecology and Phycology, Institute of Biological Sciences, University of Rostock, Rostock, Germany, ${ }^{2}$ Functional Ecology, Alfred-Wegener-Institute, Helmholtz-Centre for Polar and Marine Research, Bremerhaven, Germany, ${ }^{3}$ Analytical and Technical Chemistry, Institute of Chemistry, University of Rostock, Rostock, Germany, ${ }^{4}$ GEOMAR Helmholtz Centre for Ocean Research Kiel, Kiel, Germany
\end{abstract}

Warming and acidification of the oceans as a consequence of increasing $\mathrm{CO}_{2}$-concentrations occur at large scales. Numerous studies have shown the impact of single stressors on individual species. However, studies on the combined effect of multiple stressors on a multi-species assemblage, which is ecologically much more realistic and relevant, are still scarce. Therefore, we orthogonally crossed the two factors warming and acidification in mesocosm experiments and studied their single and combined impact on the brown alga Fucus vesiculosus associated with its natural community (epiphytes and mesograzers) in the Baltic Sea in all seasons (from April 2013 to April 2014). We superimposed our treatment factors onto the natural fluctuations of all environmental variables present in the Benthocosms in so-called delta-treatments. Thereby we compared the physiological responses of $F$. vesiculosus (growth and metabolites) to the single and combined effects of natural Kiel Fjord temperatures and $\mathrm{pCO}_{2}$ conditions with a $5^{\circ} \mathrm{C}$ temperature increase and/or $\mathrm{pCO}_{2}$ increase treatment (1100 ppm in the headspace above the mesocosms). Responses were also related to the factor photoperiod which changes over the course of the year. Our results demonstrate complex seasonal pattern. Elevated $\mathrm{pCO}_{2}$ positively affected growth of $F$. vesiculosus alone and/or interactively with warming. The response direction (additive, synergistic, or antagonistic), however, depended on season and daylength. The effects were most obvious when plants were actively growing during spring and early summer. Our study revealed for the first time that it is crucial to always consider the impact of variable environmental conditions throughout all seasons. In summary, our study indicates that in future $F$. vesiculosus will be more affected by detrimental summer heat-waves than by ocean acidification although the latter consequently enhances growth throughout the year. The mainly negative influence of rising temperatures on the physiology of this keystone macroalga may alter and/or hamper its ecological functions in the shallow coastal ecosystem of the Baltic Sea.

Keywords: bladder wrack, climate change, laminarin, mannitol, mesocosm, multi-factorial change, Phaeophyceae, seasonal growth 


\section{INTRODUCTION}

The most wide-spread effects of global environmental change are warming and acidification of the oceans as a consequence of rising $\mathrm{CO}_{2}$-concentrations. The increase of the atmospheric $\mathrm{CO}_{2}$ partial pressure $\left(\mathrm{pCO}_{2}\right)$ enhanced the greenhouse effect and led to an annual rise in mean sea-surface temperature by $0.5-1^{\circ} \mathrm{C}$ per decade since the second half of the twentieth century in northern European seas (MacKenzie and Schiedek, 2007; Elken et al., 2015). Correspondingly, surface waters in the Baltic Sea have warmed in all seasons since 1985 (HELCOM, 2013). Atmospheric $\mathrm{CO}_{2}$ concentration is expected to rise to $800-1100 \mathrm{ppm}$ by the year 2100 (Caldeira and Wickett, 2005; Orr et al., 2005; Bindoff et al., 2007) and further increases of sea-surface temperatures of the Baltic Sea by $3-6^{\circ} \mathrm{C}$ are predicted until the end of the century (Gräwe et al., 2013; Elken et al., 2015). Enhanced mean $\mathrm{pCO}_{2}$ in sea-surface waters will cause a $\mathrm{pH}$ decrease termed "ocean acidification" of $0.1-0.5$ units in the surface ocean by the end of the century (Feely et al., 2004; Sabine et al., 2004; Caldeira and Wickett, 2005; Orr et al., 2005). Global change will probably operate through combinations and interactions of multiple concurrent abiotic changes (e.g., temperature, $\mathrm{pCO}_{2}$, $\mathrm{pH}$, eutrophication, deoxygenation) that are likely to impact multiple organisms as well as their biotic interactions in the Baltic Sea (Alsterberg et al., 2013; Eklöf et al., 2015).

Marine communities in coastal ecosystems are threatened by a wide range of anthropogenic stressors including eutrophication and habitat fragmentation (Lotze et al., 2006; Worm and Lotze, 2006; Coleman and Kelaher, 2009; Coleman et al., 2011). These will interact with increasing sea-surface temperature and $\mathrm{pCO}_{2}$ which are of fundamental importance to marine primary producers such as macroalgae (e.g., Connell and Russell, 2010; Harley et al., 2012; Koch et al., 2013). In the face of global change it is predicted that the importance of habitat-forming foundation species (e.g., macroalgae) in maintaining ecosystem function and services will increase because they can buffer environmental stress by modifying their environment (Bruno et al., 2003; Halpern et al., 2007; Wahl et al., 2015a).

In the Baltic Sea Fucus vesiculosus $\mathrm{L}$. is the most common large, canopy-forming and hence structurally important macroalga forming conspicuous belts along rocky and stony coasts (Kautsky et al., 1992; Torn et al., 2006; Rönnbäck et al., 2007). As a result of its high biomass and productivity Fucus stands provide habitat and protection for a diverse community in the Baltic Sea consisting of $\sim 30$ species of Fucus associated macrofauna and macroscopic epiflora (e.g., Haage, 1975, 1976; Aneer et al., 1983; Kautsky and Kautsky, 1989). One reason for the high species diversity is probably the perennial and architecturally complex nature of the Fucus belt, which provides numerous ecological niches. Fucus communities offer important food sources for numerous organisms, thereby supporting complex trophic interactions (Kautsky et al., 1992; Middelboe et al., 2006; Korpinen et al., 2007; Rohde and Wahl, 2008). Structural changes of the F. vesiculosus community will also strongly influence the ecology of the associated organisms. The structure and function of the $F$. vesiculosus ecosystem in the shallow subtidal of the Baltic Sea has been attributed to different factors (Kautsky and van der Maarel, 1990), such as growth and primary production, which in turn are controlled by various biotic and abiotic stressors (Wahl et al., 2011).

The sensitivity of $F$. vesiculosus to environmental changes is suggested by the pronounced shoaling and shrinking of Baltic populations as reported for the last five decades (Kautsky et al., 1986; Vogt and Schramm, 1991; Berger et al., 2004; Torn et al., 2006). In the southwestern Baltic, for instance, the Fucus belt decreased its lower depth distribution from 10 to $2 \mathrm{~m}$ and decreased in area by $>95 \%$ (Vogt and Schramm, 1991; Torn et al., 2006). These severe changes in distribution and biomass have recently been attributed to multifactorial stressors (Wahl et al., 2011). A combination of factors which include increasing eutrophication, warming and sedimentation on the ecosystem level, resulted in more shading, competition with epiphytic microalgae, ephemeral fast-growing filamentous, and/or thermophilic invasive macroalgae, lack of suitable substrata for attachment of $F$. vesiculosus zygotes and increased grazing pressure, finally leading to a high mortality of this macroalga (Kautsky et al., 1986; Lotze and Schramm, 2000; Lehvo and Bäck, 2001; Berger et al., 2004; Korpinen et al., 2007; Weinberger et al., 2008).

Multiple stressors may influence ecosystem functioning by interacting in a non-additive way, either synergistically or antagonistically, which likely produce complex interactive ecosystem responses (Darling and Côté, 2008; Russell et al., 2009; Wahl et al., 2011; Wernberg et al., 2012; Brown et al., 2013). However, year-round studies on the combined effect of multiple factors (e.g., ocean acidification and warming) on a multi-species assemblage, which is ecologically realistic and relevant, are still scarce. Therefore, we exposed F. vesiculosus and its associated community (epiphytes, invertebrate mesograzers, mussels, starfish, polychaetes) to the orthogonally crossed factors warming and acidification, in levels expected for the shallow western Baltic Sea region within the next 100 years (BACC II Author Team, 2015) in four seasonal near natural climate change scenarios using benthic mesocosms (Kiel Outdoor Benthocosms).

Ocean acidification primarily impacts calcifying organisms and $\mathrm{CO}_{2}$-limited marine algae and seagrass (e.g., Raven et al., 2005; Kroeker et al., 2010, 2013). Photosynthesis of many marine macroalgae is not carbon-saturated at current dissolved inorganic carbon (DIC) levels in seawater (reviewed in Koch et al., 2013). Most species acquire dissolved inorganic carbon in the form of $\mathrm{CO}_{2}$ with many species additionally possessing carbon concentrating mechanisms (CCMs) to satisfy their photosynthetic carbon demand (reviewed in Raven et al., 2011). CCMs enable these algae to acquire inorganic carbon from the seawater by the direct uptake of $\mathrm{HCO}_{3}^{-}$and/or its conversion into $\mathrm{CO}_{2}$ through the action of internal and/or external carbonic anhydrase (Badger, 2003; Giordano et al., 2005; Hepburn et al., 2011), however these mechanisms come with an additional enzymatic cost compared to passive assimilation of $\mathrm{CO}_{2}$ (Raven, 1997; Beardall et al., 1998). Consequently, an increase in $\mathrm{pCO}_{2}$ might boost the growth of macroalgae through the use of the energy saved from the down-regulation of the energy-consuming CCMs by facilitating their access to carbon (in the form of 
$\mathrm{CO}_{2}$; Johnston and Raven, 1990; Beardall and Giordano, 2002; Giordano et al., 2005; Wu et al., 2008). Therefore, effects of high $\mathrm{pCO}_{2}$ on photosynthesis and growth of many non-calcifying macroalgae are thought to be stimulating (Gordillo et al., 2001; Wu et al., 2008; Olischläger et al., 2012; Koch et al., 2013). The effects of $\mathrm{CO}_{2}$-enrichment on non-calcifying algae, however vary strongly when interacting with other abiotic factors (e.g., nutrients, irradiance, temperature; Gordillo et al., 2001; Zou and Gao, 2009; Connell and Russell, 2010; Russell et al., 2011; Sarker et al., 2013). Physiological studies on growth responses of Fucus species are contradictionary as it was demonstrated that elevated $\mathrm{CO}_{2}$ levels can enhance growth of Fucus species due to carbon fertilization (Nygård and Dring, 2008; Saderne, 2012) or reduce growth of $F$. vesiculosus probably when interacting with other abiotic parameters like nutrients and/or irradiance levels (Gutow et al., 2014).

Heat waves as unpredictable extreme weather conditions may enhance the negative effects of ocean warming on the physiological performance and fitness of macroalgal populations (Bartsch et al., 2013), and may result in poleward shifts to avoid increasing warming (Müller et al., 2009; Wernberg et al., 2010, 2011; Bartsch et al., 2012; Jueterbock et al., 2013). As algae have the capacity to physiologically acclimatize to temperature changes, they are able to optimize growth as well as photosynthesis over a wide range of temperatures (Davison et al., 1991; Kübler and Davison, 1995; Eggert et al., 2006). While seasonal changes in temperature are generally predictable and can be compensated by acclimation processes and/or physiological plasticity of individual organisms (Davison and Pearson, 1996; Kingsolver and Huey, 1998), the irregular occurrence of extreme temperature conditions can seriously increase mortality (Roth et al., 2010; Winters et al., 2011). Not only thermal limits but also sub-lethal conditions may cause stress by impairing physiological repair mechanisms or by inducing accumulation of harmful intermediates such as reactive oxygen species (Weidner and Ziemens, 1975; Davison and Pearson, 1996).

The perennial life-cycle of $F$. vesiculosus permits to integrate effects of environmental conditions over time as reflected in growth rates (Carlson, 1991; Lehvo et al., 2001; Kraufvelin et al., 2012). However, assessing growth of a morphologically complex macroalga with a differentiated thallus like $F$. vesiculosus is neither simple nor uniform. The three-dimensional habit of $F$. vesiculosus has to be considered in growth measurements as apical length elongation, thallus area and biomass as well as dichotomizing of the frondage ("bushiness") will not develop simultaneously (Knight and Parke, 1950). Variations between these growth parameters may depend on environmental factors and season.

The optimal growth temperature for western Baltic $F$. vesiculosus ranges between 10 and $24^{\circ} \mathrm{C}$ and the upper survival temperature is between 26 and $27^{\circ} \mathrm{C}$ if exposed for 3 weeks to laboratory conditions (Graiff et al., 2015a). Shallow water temperature may already reach more than $30^{\circ} \mathrm{C}$ for short periods during summer in the western Baltic Sea (Wahl et al., 2010; HELCOM, 2013). These heat-waves are expected to become more frequent and intense due to global warming (Meehl and Tebaldi, 2004; Diffenbaugh et al., 2005; Vasseur et al., 2014).
Therefore, extremely warm and fluctuating conditions may lead to a frequent exposure of algae to sub-lethal temperatures, and may further impact acclimation potential to upper lethal temperatures in F. vesiculosus.

Consequently, the determination of temperature requirements in combination with the acclimation potential of $F$. vesiculosus in the Baltic Sea are crucial factors to assess ecosystem resilience under predicted climate change scenarios. In order to better understand the impact of ocean acidification and warming, their interactions and feedback loops, it is important to study the acclimation potential over time in a multi-species assemblage. Until now, little is known about the seasonal phenotypic acclimation of physiological performance traits (growth and metabolites) of $F$. vesiculosus from the western Baltic Sea under a near natural climate change simulation. Effects of future ocean warming and increasing $\mathrm{pCO}_{2}$ on $F$. vesiculosus may vary seasonally according to natural growth and reproduction periods. Our main objectives were to quantify and distinguish the relative and/or interactive (additive, synergistic, or antagonistic) effects of ocean acidification in combination with concurrent warming on growth and basic biochemical parameters of $F$. vesiculosus. Furthermore, we tested if the impact of these global change factors (single and combined) on $F$. vesiculosus performance and tolerance vary with season and are related to the factor photoperiod which changes over the course of the year.

\section{MATERIALS AND METHODS}

\section{Sampling Site}

All $F$. vesiculosus $L$. specimens were collected in each season (spring: 2 April 2013; summer: 2 July 2013; fall: 8 October; winter: 14 January 2014) from a depth of $0.2-1 \mathrm{~m}$ in the non-tidal Kiel Fjord, western Baltic $\left(54^{\circ} 27^{\prime} \mathrm{N} ; 10^{\circ} 12^{\prime} \mathrm{E}\right)$, where this species forms dense and almost monospecific stands on single stones surrounded by soft sediments. We chose Fucus individuals of different sizes and volumes, growing on small stones. All plants were left attached to their natural rock substratum. After sampling, the macrophytes, their epiphytes and the associated fauna were immediately placed into water-filled buckets (protected from light and desiccation) and transported to the experimental site at the GEOMAR Helmholtz Centre for Ocean Research. Prior to their distribution to the experimental units, Fucus individuals were sorted into three size classes $(<15 \mathrm{~cm}, 15-30 \mathrm{~cm},>30 \mathrm{~cm})$, identified by numbered tags and motile fauna was removed by submerging them for 10-20s in freshwater (Holmlund et al., 1990). The three most important mesograzers (Littorina littorea, Idotea sp. and Gammarus sp.) caught with the collected Fucus individuals were sorted and counted. The initial amount of grazers given into the system varied between experiments according to the natural variability of their abundance across seasons but was identical among treatment levels and replicates within a seasonal experiment (for details see Werner et al., 2015).

\section{Seasonal Benthocosm Experiments}

In order to assess the seasonal variations of separate and joint effects of simulated ocean warming and acidification on 
the system, all four experiments were conducted consecutively within 1 year. All experiments were carried out in the Kiel Outdoor Benthocosms (KOB), a permanent experimental facility installed outdoors on a jetty at the inner Kiel Fjord $\left(54^{\circ} 20^{\prime} \mathrm{N}\right.$; $10^{\circ} 09^{\prime} \mathrm{E}$ ). The first experiment ran from 4 April to 19 June 2013 (spring experiment), the second from 4 July to 17 September 2013 (summer experiment), the third from 10 October to 18 December (fall experiment) and the last one from 16 January to 1 April 2014 (winter experiment), each for at least 10 weeks.

The experimental facility allows for testing near natural scenarios (Wahl et al., 2015b), not only in terms of multiple abiotic factors that can be manipulated simultaneously, but also with regard to the community being assessed, i.e., multiple species, functional groups and trophic levels. Twenty plants of $F$. vesiculosus growing on their rock substrata with their associated organisms such as micro- and macro-epiphytes, their bacterial biofilm as well as mesograzers, mussels and starfish were established in each experimental unit. In the Benthocosms the rock substrata of each Fucus was placed in small plastic dishes ( $=14 \mathrm{~cm}, h=4 \mathrm{~cm}$ ) which were fixed on a grating by cable ties in order to maintain an even distribution of the plants despite the water current. The grating was suspended at a water depth of $40 \mathrm{~cm}$. Furthermore, to complete the F. vesiculosus community the three main mesograzers (Littorina littorea, Idotea sp., and Gammarus sp.) were added to the Benthocosms in previously counted and seasonally adjusted numbers.

At the end of each experiment the micro- and macroepiphytes as well as the mesograzers were sampled per experimental unit but were analyzed separately (Werner et al., 2015). For estimating microepiphyte biomass growing on the Fucus thalli, one apical branch per thallus of defined weight (1.5-2 mg dry weight) was carefully scraped off. In short the sample was homogenized and fixed for microscopic identification and counting. Microepiphyte biomass was then estimated from cell biovolume converted to carbon content. Macroepiphytes were collected from the Fucus thalli that also had been sampled for microepiphyte analysis and were expressed as dry weight. During final sampling all mesograzers were removed from the experimental tanks. They were identified, sorted, counted and total grazer abundance was determined. For further details see Werner et al. (2015). The micro- and macroepiphytes as well as the mesograzers showed seasonal growth patterns under ambient conditions with highest biomass of microepiphytes in spring and at the end of the winter experiment (March), and lowest at the end of the fall experiment (December). Biomass of filamentous macroepiphytes was highest in late summer and lowest in fall in the ambient treatment. Total grazer abundance under ambient conditions was significantly higher in summer as compared to any other season. In spring, fall, and winter grazers showed similar low abundances. Generally, warming had significantly stronger effects on the epiphytes and mesograzers associated with Fucus than increased $\mathrm{pCO}_{2}$. In the spring experiment, warming increased the biomass of filamentous macroepiphytes significantly, whereas it had no effect on the biomass of microepiphytes and total grazer abundance. However, in late summer, warming induced a cascading effect impacting the entire Fucus system. In this period total grazer abundance collapsed under warming, whereas the biomass of microepiphytes and filamentous macroepiphytes showed a significant increase (for details see Werner et al., 2015).

A detailed technical description of the KOB, their installation, programming and monitoring is given in Wahl et al. (2015b). The Benthocosms comprise 12 tanks, each holding a water volume of $1.4 \mathrm{~m}^{3}$. The experimental units are exposed to ambient light (irradiance and photoperiod) conditions year-round. They are equipped with gas-tight, transparent covers and can be controlled independently for environmental factors such as seawater $\mathrm{pCO}_{2}$ and temperature. The foil (Lumisol clear, Folitec, Westerburg, Germany) of the covers permits all wavelengths of the solar spectrum to penetrate (Wahl et al., 2015b). The Benthocosms were supplied with a constant flow of non-filtered seawater taken from the Kiel Fjord, in close vicinity to the experimental platform and from $1 \mathrm{~m}$ depth resulting in an exchange of water once per day. A circulation pump (ATK-MP10041, AQUA LIGHT, Germany or Kripsol OK33B, Kripsol Grupo, Spain, $10^{4} \mathrm{~L} \mathrm{~h}^{-1}$ ) produced a current inside each tank to mimic water movements as close as possible to natural conditions.

Temperature was controlled by aquarium controllers (Profilux-3ex and Expansion Box, powerbars of the types 6D PAB and STDL4-4, GHL Advanced Technology, Kaiserslautern, Germany) and adjusted via electrical heat exchangers (Titan, 2000; Aqua Medic, Bissendorf, Germany) and/or internal heating elements (Schego Titan, 600 Watt, Schemel and Goetz, Offenbach/ Main, Germany). For seawater $\mathrm{pCO}_{2}$ manipulations pure $\mathrm{CO}_{2}$ (Linde Gas, Pullach, Germany) was injected into the headspace under the gas-tight cover of each experimental unit. The $\mathrm{pCO}_{2}$ inside the headspace was automatically controlled by injection of $\mathrm{CO}_{2}$ maintaining a treatment level of $\sim 1100$ ppm $\mathrm{CO}_{2}$ in the atmosphere under the cover (Scenty, HTK, IR Spectroscopy, Hamburg, Germany). A wave generator regularly induced water motion and thereby promoted diffusion of $\mathrm{CO}_{2}$ from the headspace into the water column.

The key variables temperature and $\mathrm{pH}$ in the Benthocosms were continuously logged by sensors (platinum resistance thermometer PT1000 and gel-electrolyte filled glass electrode, GHL Advanced Technology, Kaiserslautern, Germany). To examine the drift of the continuously logging $\mathrm{pH}$ sensors the $\mathrm{pH}$ of the tanks was additionally measured daily using hand-held and calibrated sensors (Seven Multi+InLab Expert Pro, Mettler Toledo GmbH, Giessen, Germany). The $\mathrm{pH}$ electrode was calibrated with National Bureau of Standards (NBS) pH-buffer (4.001, 6.865). Properties of the carbonate system in the four climate combinations were regularly measured by discrete water sampling and subsequent analysis, e.g., for total alkalinity (TA) and nutrients (twice per week) as well as for dissolved inorganic carbon (DIC) in monthly intervals. Samples for seawater TA and DIC were taken directly from the experimental units at a fixed time (9.00-11.00 a.m.) 1 day prior to each sampling. TA samples were measured using a titration unit with associated sample changer (Titroline alpha plus, SI Analytical Mainz, Germany). Water samples for DIC analysis were measured via coulometric titration (Johnson et al., 1993; Winde et al., 2014). TA and DIC measurements were calibrated using certified seawater standards (Dickson, Scripps Institution of Oceanography, San Diego; e.g., Dickson et al., 2007). Data of TA, DIC, salinity, and temperature were used to calculate the partial pressure of 
$\mathrm{CO}_{2}\left(\mathrm{pCO}_{2}\right.$ ) with the CO2SYS program for Excel (Pierrot et al., 2006). Nutrient samples were filtered and stored frozen $\left(-20^{\circ} \mathrm{C}\right)$ until measurement of ammonium-, phosphate- and nitrate salts using a QuAAtro nutrient analyzer (SEAL Analytical GmbH, Norderstedt, Germany).

\section{Temperature and Carbonate Chemistry Manipulations}

The effects of future ocean warming were tested by contrasting the levels ambient temperature of Kiel Fjord water vs. warming $\left(+5^{\circ} \mathrm{C}\right.$ relative to fjord water) which were full-factorially crossed with two levels of $\mathrm{pCO}_{2}$ (ambient vs. varying around $1100 \mathrm{ppm}$ ). To evaluate single and interactive effects of warming and elevated $\mathrm{pCO}_{2}$ on growth and biochemical parameters of $F$. vesiculosus, four different treatments were tested: (1) natural temperature in the Kiel Fjord and ambient $\mathrm{pCO}_{2}$ (control), (2) expected elevated future $\mathrm{pCO}_{2}\left(+\mathrm{CO}_{2}\right)$ in natural temperature, (3) elevated temperature (+Temp) with ambient $\mathrm{pCO}_{2}$, and (4) elevated temperature combined with expected elevated future $\mathrm{pCO}_{2}$ $\left(+\right.$ Temp $\left.+\mathrm{CO}_{2}\right)$. Importantly, to take into account the natural fluctuations of all environmental variables we superimposed our treatment factors onto these in the Benthocosms, i.e., delta-treatments in all seasons were applied (natural Kiel Fjord temperature plus $5^{\circ} \mathrm{C}$ and $\mathrm{pCO}_{2}$ varying around $1100 \mathrm{ppm}$ in the headspace above the Benthocosms). Both manipulations were chosen according to climate change predictions for shallow coastal Baltic habitats over the next 100 years (Gräwe et al., 2013; BACC II Author Team, 2015). Each treatment combination was replicated three times. Before starting the experiments the algae and the associated community were acclimated to the Benthocosm conditions for 2 days under ambient conditions. The temperature at the warming treatments was elevated by $2^{\circ} \mathrm{C}$ on the second day and by $3^{\circ} \mathrm{C}$ on the third day to achieve a $5^{\circ} \mathrm{C}$ elevated temperature compared to the natural Kiel Fjord temperature at the fourth day. In none of the experiments this initial warming reached critically high values (i.e., $26^{\circ} \mathrm{C}$, Graiff et al., 2015a). The $\mathrm{CO}_{2}$ was injected from the second day onwards into the headspace above the tanks.

\section{Monitoring of Environmental Conditions During the Experiments}

Throughout the course of each experiment water temperature was continuously logged in every Benthocosm. In addition, the seasonal variation in irradiance was measured in the Kiel Fjord at $0.5 \mathrm{~m}$ water depth using light loggers (Onset computer corporation, Bourne, MA, USA) and is shown in the study of Rickert et al. (2015). Daylength was calculated for the location of the Kiel Benthocosms with the Online-Photoperiod Calculator V 1.94 L by L. Lammi (http://www.sci.fi/ benefon/sol.html). Variations in sea water chemistry like $\mathrm{CO}_{2}$ parameters $(\mathrm{pH}, \mathrm{DIC}$, $\mathrm{TA}$, and $\left.\mathrm{pCO}_{2}\right)$ and nutrient concentrations $\left(\mathrm{PO}_{4}, \mathrm{NO}_{3}\right)$ were measured regularly and are presented in detail in Wahl et al. (2015b). Salinity was continuously logged at the institute pier $(<100 \mathrm{~m}$ distant) by GEOMAR. The original raw data on the environmental key parameters of each Benthocosm are available at PANGAEA ${ }^{\circledR}$ data platform (http://doi.pangaea.de/10.1594/ PANGAEA.842739).

\section{Growth Measurements}

Growth was assessed as apical length increase and biomass change as well as change of apex numbers of the Fucus individuals in the Benthocosms. For these measurements Fucus individuals of $15-25 \mathrm{~cm}$ length and apparently of equal vigor, growing on stones $(10-15 \mathrm{~cm}$ in diameter), were chosen. Other organisms on these stones were removed leaving only one Fucus individual growing from a single holdfast per stone.

Growth was measured regularly as length of the apical tips using a caliper gauge. For this, a small hole was punched $2 \mathrm{~cm}$ from the ends of 12 vegetative actively growing apices and marked with colored nylon ties on each Fucus specimen at the start of the experiment. This marking was done to avoid confusion with bite marks of grazers. After 14 or 28 days, depending on the season, the tip lengths were measured again and the mean value of the length increase of these 12 apices was calculated as the growth rate of each Fucus individual. Additionally, growth was measured as wet mass of each Fucus individual. The complete F. vesiculosus individuals were weighed (EMB1200-1, Kern, Balingen, Germany) for total wet mass after cleaning of epiphytes and standardized drying (i.e., gently shaking the plant five times and blotting of surface water between dishtowels) at the beginning and at the end of each experiment. Relative growth rates (RGR) were calculated according to Lüning (1990) using a linear formula for length:

$$
R G R\left(\% d^{-1}\right)=100 \frac{x_{t}-x_{0}}{x_{0} * t}
$$

and a logarithmic formula for biomass change for wet mass:

$$
R G R\left(\% d^{-1}\right)=100 \frac{\ln \left(m_{t}\right)-\ln \left(m_{0}\right)}{t}
$$

where $x_{0}$ represents initial length $(\mathrm{cm})$ and $m_{0}$ the initial wet mass $(\mathrm{g}), x_{t}$ the length $(\mathrm{cm})$ and $m_{t}$ the wet mass $(\mathrm{g})$ after $t$ days $(\mathrm{d})$.

The apex numbers of the $F$. vesiculosus individuals were counted at the beginning and at the end of each Benthocosm experiment. One apex was defined as the incision of a dichotomy $\geq 0.5 \mathrm{~cm}$. Relative changes of individual frond apices numbers of F. vesiculosus individuals $\left(\% \mathrm{~d}^{-1}\right)$ were calculated in order to standardize changes according to the number of experimental days.

\section{Biochemical Features of Fucus}

In order to assess the biochemical parameters of $F$. vesiculosus individuals after growing for 3 months under the four different treatments in every season the vegetative apices were cut off, cleaned of epibiota and freeze-dried for further analyses. Only apices were used because older thallus parts are mainly metabolically inactive (Carlson, 1991) and have not been formed during the course of the experiment. At the beginning of each experiment, vegetative apices without visible epiphytes of 12 initial $F$. vesiculosus individuals were freeze-dried to document the initial biochemical status of $F$. vesiculosus in its native habitat. For analyzing carbon and nitrogen contents, freeze-dried algal material was ground to powder using mortar and pistil, and three subsamples of $2 \mathrm{mg}$ were loaded and packed into tin cartridges 
$(6 \times 6 \times 12 \mathrm{~mm})$. These packages were combusted at $950^{\circ} \mathrm{C}$ and the absolute contents of $\mathrm{C}$ and $\mathrm{N}$ were automatically quantified in an elemental analyzer (Elementar Vario EL III, Germany) using acetanilide as standard according to Verardo et al. (1990). Mannitol was extracted from three freeze-dried subsamples of $10-20 \mathrm{mg}$ powdered alga material and quantified, following the HPLC method described by Karsten et al. (1991). Laminarin concentration was examined using cold water extraction $(6 \mathrm{~mL})$ from freeze-dried powdered apex material (200 mg) according to the new method described by Graiff et al. (2015b). Additionally, alginates were precipitated with ethanol (>99.7\%) and formic acid (98\%) to avoid disturbance of the measurements. The purified extracts were analyzed and laminarin identified as well as quantified using liquid chromatography-mass spectrometric analysis (LC-MS).

\section{Statistical Analyses}

Differences in the relative length growth rates of F. vesiculosus between the treatments were analyzed with repeated measures analysis of variance ( $\mathrm{rm}$ ANOVA), with the within-subject factor time (day) and the between-subject factor treatments $\left(\mathrm{pCO}_{2}\right.$ and temperature) for every experiment separately. If the assumption of sphericity (Mauchly test) was not met, the univariate approach with Greenhouse-Geisser adjusted degrees of freedom and $p$ values for the $F$-test was applied.

In order to evaluate the interactive effect of temperature and $\mathrm{pCO}_{2}$ on all variables measured (relative length growth rates, biomass change, relative change of individual frond apex numbers, $\mathrm{CN}$ ratio, $\mathrm{C}, \mathrm{N}$, and mannitol content) at the end of every Benthocosm experiment, Two-way ANOVAs were used with temperature and $\mathrm{pCO}_{2}$ as fixed factors. When the analysis did not show significant interactions, a One-way ANOVA was carried out for each factor separately. Furthermore, to assess seasonal differences of $\mathrm{CN}$ ratios, $\mathrm{C}, \mathrm{N}$, and mannitol contents (\% DW) of the initial biochemical status of $F$. vesiculosus in its native habitat One-way ANOVAs were applied. Prior to the use of ANOVAs, data were tested for normality with the KolmogorovSmirnov or Shapiro-Wilk test and for homogeneity of variances with the Levene's test. When the analysis revealed significant differences, pairwise comparisons between means were further explored using a post hoc Tukey's honest significant difference test. Data were analyzed using SPSS Statistics 20 (IBM, Armonk, NY, USA) and the R software (R. Development Core Team, 2014).

\section{RESULTS}

\section{Environmental Conditions During the Experiments}

The natural water temperature of the Kiel Fjord showed a clear seasonal pattern with rising mean temperatures in spring and early summer (April-June), reaching maximal values (24.1$24.8^{\circ} \mathrm{C}$ ) in July/August and declining temperatures during fall and early winter (September-December). In January a minimal water temperature of $4.2 \pm 1.4^{\circ} \mathrm{C}$ was reached and afterwards the temperature increased from February to March again (Table S1). Accordingly, the irradiance measured in the Kiel Fjord varied with season showing increasing intensities in late spring and early summer (April-June), maxima in July/August and continually decreasing intensities in fall and winter (Rickert et al., 2015). During the course of the spring experiment daylengths increased from 14 to $17 \mathrm{~h}$ and in late summer decreased from 17 to $13 \mathrm{~h}$. In fall daylengths decreased further from 10 to $8 \mathrm{~h}$ and during the course of the winter experiment they increased again from 8 to $12 \mathrm{~h}$. In spring and fall water temperature correlated positively with daylength (spring: $R^{2}=0.95$; fall: $R^{2}=0.99$ ), in contrast to summer and winter (summer: $R^{2}=0.21$; winter: $R^{2}=0.04$ ).

The natural $\mathrm{pH}$ of the Kiel Fjord surface water was high (8.5) in spring (April-June) and low (7.7) in fall (OctoberNovember). Additionally, upwelling of $\mathrm{CO}_{2}$ - and nutrientenriched deep water has caused stochastic changes in the nutrient and carbonate systems, as well as of the $\mathrm{pH}$ of the Kiel Fjord surface waters. During spring and late summer the water was $\mathrm{CO}_{2}$ under-saturated $(100-350 \mathrm{ppm})$ in contrast to fall and winter (September-March) when the water column was $\mathrm{CO}_{2}$ supersaturated (500-1000 ppm). In the Benthocosms containing the macroalgae-based communities, the in situ seasonal (and stochastic) fluctuations were altered by the diurnal metabolic activity of the organisms (for further details see Wahl et al., 2015b). The $\mathrm{pH}, \mathrm{pCO}_{2}$, TA, and DIC differed between the applied treatments and between seasons (Table S2). The overall mean effect of head space enrichment with $\mathrm{CO}_{2}$ from ambient (380$450 \mathrm{ppm}$ ) to $1050-1100 \mathrm{ppm}$ resulted in a $\mathrm{pH}$ reduction of the tank water by $0.18 \pm 0.08 \mathrm{pH}$ units (Wahl et al., 2015b). The $\mathrm{pCO}_{2}$ concentration in the water of the control tanks varied during the course of 1 year between $130 \pm 57$ and $886 \pm 284$ ppm compared to the increased $\mathrm{pCO}_{2}$ treatment $\left(+\mathrm{pCO}_{2}\right)$ which varied between $297 \pm 192$ and $1313 \pm 397$ ppm (monthly means). In the warming treatment under ambient $\mathrm{CO}_{2}$ conditions the $\mathrm{pCO}_{2}$ varied between $220 \pm 121$ and $1373 \pm 343$ ppm compared to the $\mathrm{pCO}_{2}$ of the warm and acidified conditions which varied between $503 \pm 402$ and $1585 \pm 263$ ppm (for details see Wahl et al., 2015b). In all situations the mean difference between the ambient and increased $\mathrm{CO}_{2}$ treatment ranged between 340 and 460 ppm CO 2 (M. Böttcher and V. Winde pers. comm.).

Phosphate concentrations of the Kiel Fjord surface water were low $\left(0.19-0.48 \mu \mathrm{mol} \mathrm{L}^{-1}\right)$ throughout the spring experiment (April-June), increased in late summer $\left(0.43-1.02 \mu \mathrm{mol} \mathrm{L}{ }^{-1}\right)$, reached a maximum in October $\left(1.39 \pm 0.28 \mu \mathrm{mol} \mathrm{L}^{-1}\right)$ and decreased from November to March successively. In contrast, nitrate concentrations decreased in spring reaching lowest values in late summer $\left(0.76 \pm 0.51 \mu \mathrm{mol} \mathrm{L}^{-1}\right)$ and increased slightly in fall. Nitrate reached distinct maximal values in January (15.04 $\pm 3.32 \mu \mathrm{mol} \mathrm{L}^{-1}$ ) and decreased in February again (V. Winde pers. comm.). Phosphate as well as nitrate concentrations in the Benthocosms followed the seasonal fluctuations in the Kiel Fjord but were reduced by the uptake of macro- and micro-algae (Wahl et al., 2015b).

\section{Growth and Biochemical Features of $F$. vesiculosus}

Depending on the season temperature and to a lesser extent $\mathrm{CO}_{2}$, affected growth and biochemical features of $F$. vesiculosus and some interactive effects were revealed. 


\section{Algal Length Growth}

$F$. vesiculosus exhibited vegetative apical growth throughout the year (Figure 1). Growth of F. vesiculosus increased rapidly in late spring (April-May) and reached a maximum rate of $2.96 \pm 0.76 \%$ $\mathrm{d}^{-1}$ (relative vegetative apical length increase per day; mean \pm $\mathrm{SD}, n=3)$ in July. Later in the year growth decreased during fall (September-November) reaching a low rate $(0.40 \pm 0.27 \%$ $\mathrm{d}^{-1}$ ) in winter (December to February) before increasing again in March. This general growth pattern of $F$. vesiculosus grown at ambient environmental conditions of temperature and $\mathrm{pCO}_{2}$ (control) in the Benthocosms was also apparent at warming and/or expected future $\mathrm{pCO}_{2}$ conditions (Figure 1).

When exhibiting the growth rates either in relation to season or in relation to season and temperature as well as daylength over all treatments (Figures 1, 2), major effects of temperature and/or $\mathrm{CO}_{2}$ enrichment mostly became evident during the active growth phase which was present in spring and early summer with up to three-fold (warmed condition) and two-fold (ambient temperatures) higher growth rates compared to the rest of the year. This resulted in significant interactive effects of $\mathrm{CO}_{2}$ and

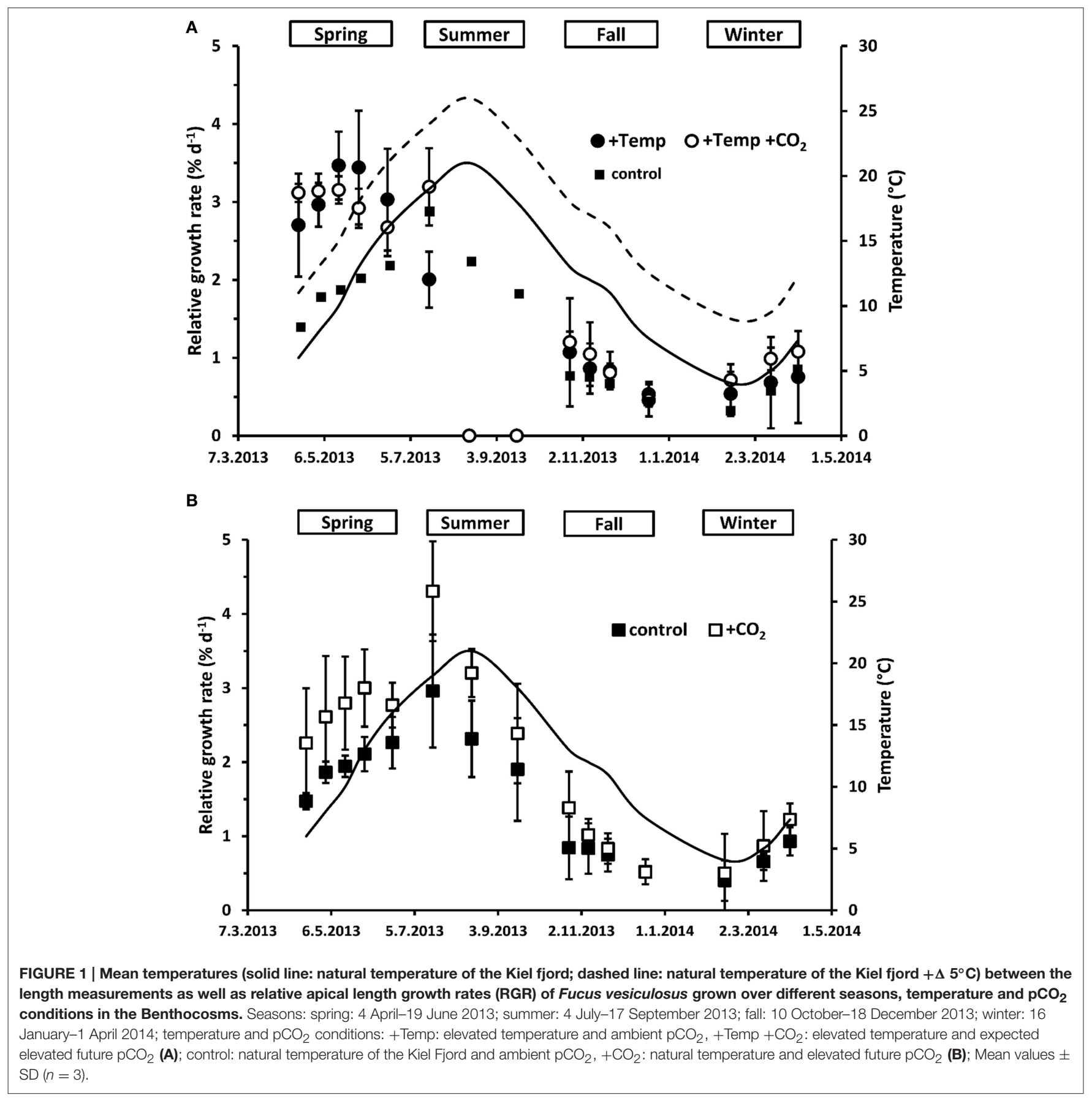




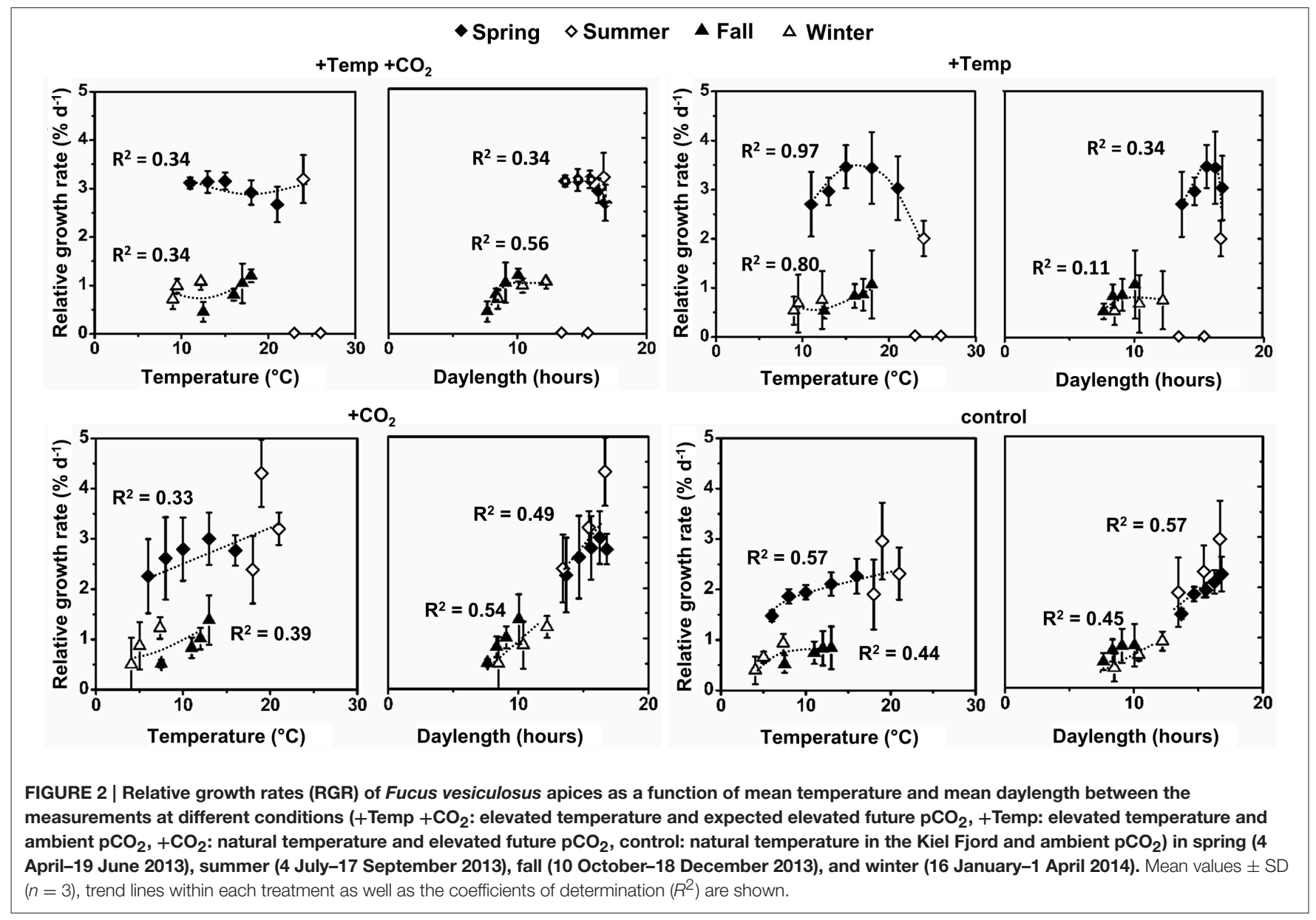

temperature over the spring experiment ( $\mathrm{rm}$ ANOVA, $F=$ $6.20, d f=1, p<0.05)$. In spring, warming significantly enhanced growth of $F$. vesiculosus by almost $40 \%$ (rm ANOVA, $F=18.36, d f=1, p=0.003)$. In the warming treatment, naturally increasing water temperatures of the Kiel Fjord during the spring experiment accelerated growth until a mean water temperature of $18^{\circ} \mathrm{C}$ was reached in May. Subsequently, growth started to decrease when water temperatures over $20^{\circ} \mathrm{C}$ were reached (Figures 1A, 2) and Fucus became increasingly fouled with epiphytic ephemeral green algae. Under warming and increased $\mathrm{CO}_{2}$ Fucus kept growth on a higher and more constant rate (Figure 2). Growth of F. vesiculosus at control conditions increased more slowly with the seasonally rising ambient temperatures until $16^{\circ} \mathrm{C}$ was reached in June, and was not overgrown by epiphytic green algae. Under ambient temperature conditions, enhanced $\mathrm{CO}_{2}$ increased growth of Fucus by almost $30 \%$ over the course of spring experiment, however this was only a non-significant tendency (rm ANOVA, $F=3.02, d f=1, p=0.12$; Figure 1B).

In the summer experiment, elevated $\mathrm{pCO}_{2}$ seemed to enhance growth in the first 2 weeks both under ambient and warmed conditions, but this enhancement was not significant (One-way ANOVA with post hoc Tukey's test, $F=2.76$, $d f=3, p=$ 0.11 ). Over the course of the summer experiment growth of
F. vesiculosus ceased completely under warmed but not under ambient temperatures ( $r m$ ANOVA, $F=22.36, d f=2, p<$ 0.001; Figure 1). Enhanced by an unexpected natural heat-wave in the fjord, warming produced peak temperatures between 27 and $30^{\circ} \mathrm{C}$ during a period of 30 days (Table S3). Subsequent to this stress phase, $F$. vesiculosus individuals showed a reddish tinge, their complete thallus tissue disintegrated and necrosis as well as deterioration of the apical meristems was obvious. This period of high water temperatures resulted in a dieback of the Fucus assemblage in the warmed treatments (Figure 1A). Even growth of Fucus individuals at ambient temperature conditions (maximal temperatures of $25^{\circ} \mathrm{C}$ ) decreased significantly in the course of the summer experiment (rm ANOVA, $F=15.59$, $d f=2, p<0.05$ ). This natural heat stress was mitigated by increased $\mathrm{CO}_{2}$ which kept growth of Fucus by $27 \%$ above the control, however this growth enhancement was not significant (rm ANOVA, $F=1.27$, $d f=2, p=0.33$, Figure $1 \mathbf{B}$ ).

During the fall experiment, growth of $F$. vesiculosus significantly decreased over time ( $\mathrm{rm}$ ANOVA, $F=24.02$, $d f=3, p<0.001$ ) reaching low growth rates in December under all treatments. During the winter experiment, growth of Fucus increased significantly from January to April (rm ANOVA, $F=25.08, d f=2, p<0.001)$ and the mean water temperature of the Kiel Fjord increased in parallel. No effects of warming or 
increased $\mathrm{CO}_{2}$ were apparent (Figures 1, 2). However, under warmed conditions Fucus thalli appeared to be more leathery and had a more reddish tinge at the end of both experiments compared to the vigorous greenish Fucus individuals under ambient temperatures.

Integrating over all seasons, growth of F. vesiculosus wellrelated to water temperature and also daylength and two patterns became obvious. In spring and summer Fucus grew stronger under long-day conditions ( $>12 \mathrm{~h}$ ) compared to growth under short-day conditions $(<12 \mathrm{~h})$ in fall and winter despite similar water temperatures (Figure 2). Under ambient temperature conditions (ambient and increased $\mathrm{CO}_{2}$ treatment) growth of Fucus related positively to water temperatures and daylength, especially in the active growth phases in spring and early summer (Figure 2). This beneficial temperature and daylength effect was enhanced by increased $\mathrm{CO}_{2}$ as indicated by a steeper slope of the trend line in comparison to growth at ambient $\mathrm{CO}_{2}$ conditions. The generally positive effect of higher temperatures was lost under warmed conditions, when an upper temperature threshold of $24^{\circ} \mathrm{C}$ was surpassed. Under warmed and long-day conditions $(>12 \mathrm{~h})$ no further growth increase was obvious compared to ambient temperature and long-day conditions (Figure 2).

\section{Comparison of Growth Parameters}

Growth of a morphologically complex macroalga with a differentiated thallus like F. vesiculosus cannot be characterized alone by elongation of the apical vegetative tips, therefore we additionally assessed the biomass change (fresh mass) as well as the change of apex numbers. Length elongation of the vegetative tips of Fucus over the complete spring experiment was high $(3.48-4.67 \mathrm{~cm})$ without significant differences between the experimental conditions (Two-way ANOVA, Table S4 and Figure 3A). On the other hand in the course of the spring experiment Fucus individuals considerably lost biomass due to denudation of the wings of the lower thallus part (Figure 3B). Additionally, during the spring experiment most of the apices became fertile. Individual fronds then developed only few dichotomies at the thallus apex due to deterioration of the receptacles (Figure 3C). No effects of warming or increased $\mathrm{CO}_{2}$ on biomass as well as apex numbers were apparent in spring (Two-way ANOVA, Tables S5, S6).

During the summer experiment warming significantly reduced Fucus growth (Two-way ANOVA, $p<0.01$, Tables S4, $S 5$, S6) resulting in a complete dieback, which indicates that the upper temperature tolerance limit of $F$. vesiculosus was exceeded. Under ambient summer temperatures apical length and biomass of Fucus increased and the apices dichotomized considerably (Two-way ANOVAs, $p<0.01$, Figure 3). Increased $\mathrm{CO}_{2}$ tended to favor length elongation, biomass and apices numbers of Fucus, but these differences were not significant (Two-way ANOVA, Tables S4, S5, S6).

Elongation of Fucus vegetative tips in the course of the complete fall $(0.63-0.73 \mathrm{~cm})$ and winter $(1.13-1.84 \mathrm{~cm})$ experiment was low and similar under all treatments. Warming provoked a loss of biomass (Two-way ANOVA, $p=0.06$, Table S5) and a significant loss of apices (Two-way ANOVA, $p<0.05$, Table S6) in fall. In fall and winter, increased $\mathrm{CO}_{2}$ enhanced

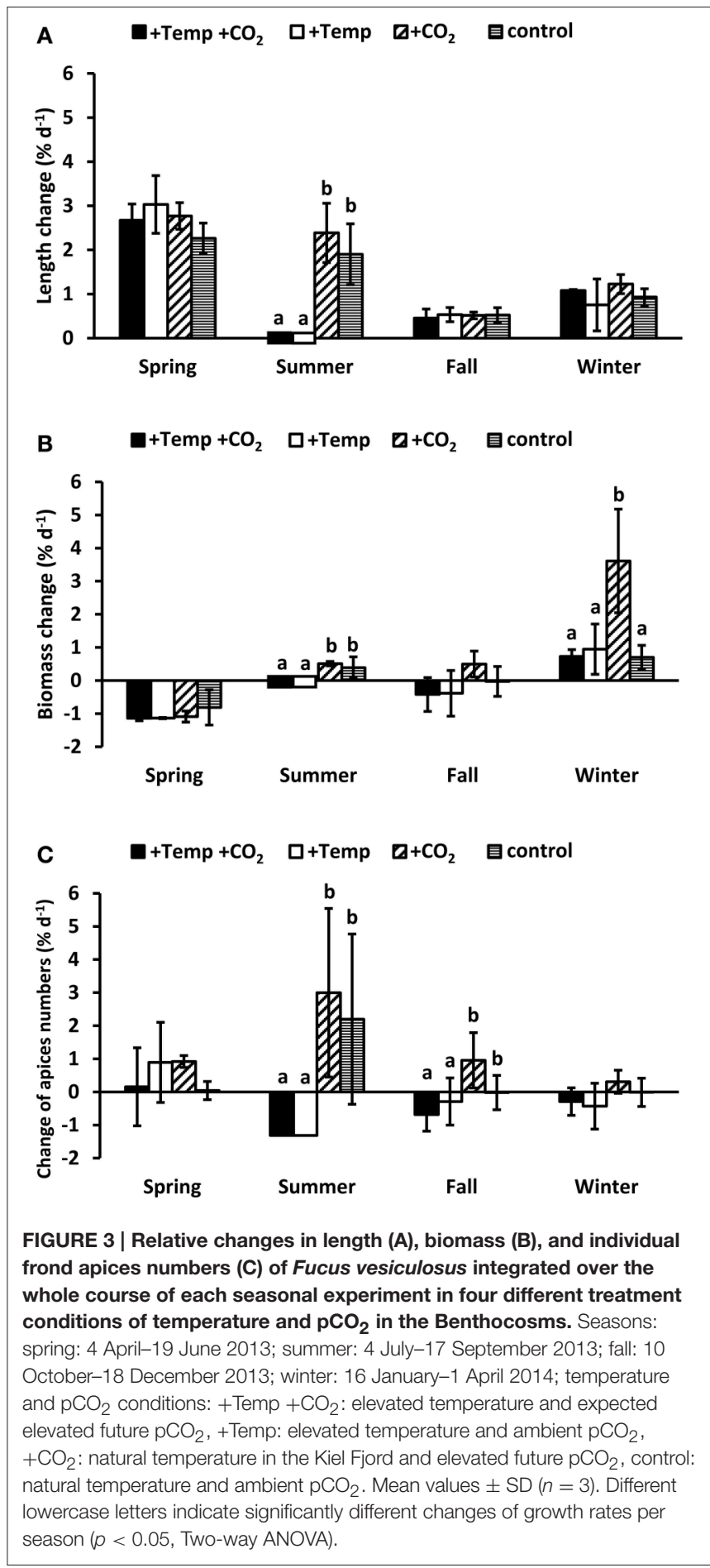

biomass and apices numbers of $F$. vesiculosus individuals compared to all other conditions (Figures 3B,C), but this effect was only significant for biomass increase in winter (One-way ANOVA, with post hoc Tukey's test, $F=7.43$, df $=3$, $p<0.05)$. During the winter experiment most of the vegetative apices developed into receptacles which made up a considerable quantity of the biomass at the end of the experiment. 


\section{C-N Composition}

The $\mathrm{CN}$ ratio, carbon, and nitrogen content of $F$. vesiculosus in its native habitat varied significantly with season (One-way ANOVAs with post hoc Tukey's test, $\mathrm{CN}: F=406.56, d f=3$, $\mathrm{C}: F=24.22, d f=3, \mathrm{~N}: 357.12, d f=3, p<0.001$, Table 1). In spring and winter $\mathrm{CN}$ ratios (April: $8.53 \pm 0.68$, January: $11.50 \pm$ 1.06) of vegetative Fucus tips were significantly lower compared to summer and fall (July: $30.59 \pm 4.73$, October: $30.31 \pm 4.68$ ). Thus, nitrogen content of Fucus tips reached maximum values in spring and winter (April: $4.32 \pm 0.42 \%$ DW, January: $2.97 \pm$ $0.29 \% \mathrm{DW}$ ) and minimum values in summer and fall (July: 1.24 $\pm 0.18 \%$ DW, October: $1.20 \pm 0.19 \%$ DW). Carbon content of Fucus showed maximum values varying between $36.62 \pm 1.30$ and $37.08 \pm 0.96 \%$ DW from April to July and significantly lower values in October and January $(35.46 \pm 0.72-33.89 \pm 0.87 \% \mathrm{DW}$, Table 1).

In accordance with the seasonal variation of carbon and nitrogen of Fucus in its native habitat, the CN ratio of Fucus was low (12.00-13.39) at the end of the winter experiment and high (29.46-34.75) at the end of the summer experiment under all treatments (Table 1). After growing in the Benthocosms for 3 months at the different experimental conditions in spring, fall and winter the $\mathrm{CN}$ ratio, carbon, and nitrogen content of
F. vesiculosus did not significantly differ between the applied treatments. Only in the course of the summer experiment $F$. vesiculosus died at elevated temperatures resulting in a significant reduction of carbon and nitrogen under warming (One-way ANOVAs with post hoc Tukey's test, $\mathrm{CN}: F=38.77, d f=3, \mathrm{C}$ : $F=955.34, d f=3, \mathrm{~N}: F=71.62, d f=3, p<0.001$, Table 1).

\section{Storage of Mannitol and Laminarin}

Seasonal variations in mannitol content were evident for $F$. vesiculosus grown in its native habitat (One-way ANOVA with post hoc Tukey's test, $F=23.18, d f=3, p<0.001$, Table 1). The accumulation of mannitol was significantly lower in winter (January: $7.41 \pm 1.51 \% \mathrm{DW}$ ) compared to the other seasons (April: $12.37 \pm 1.45 \%$ DW, July: $10.41 \pm 1.69 \%$ DW, October: $11.55 \pm 1.59 \%$ DW).

Similar to the seasonal variation, Fucus individuals accumulated high quantities (17.72-22.62\% DW) of mannitol at the end of the spring experiment (June) and low quantities (4.92-5.88\% DW) in December under all treatments (Table 1). In spring, warming decreased mannitol content of Fucus by $20 \%$, however this tendency was not significant (One-way ANOVA with post hoc Tukey's test, $F=0.67, d f=3, p=0.59$, Table 1). In summer, warming reduced mannitol significantly due to

TABLE 1 | CN ratios, C, N, mannitol, and laminarin contents (\% DW) of the initial biochemical status of Fucus vesiculosus apices in its native habitat (initial, $n=12$ ) and after growing for 3 months in different seasons, temperature, and $\mathrm{pCO}_{2}$ conditions in the Benthocosms $(n=3)$.

\begin{tabular}{|c|c|c|c|c|c|c|c|c|c|c|c|}
\hline & & & \multicolumn{2}{|l|}{$\mathrm{CN}$} & \multicolumn{2}{|l|}{ C } & \multicolumn{2}{|l|}{$\mathbf{N}$} & \multicolumn{2}{|l|}{ Mannitol } & \multirow[t]{2}{*}{ Laminarin } \\
\hline & & & & & & & & DV & & & \\
\hline \multirow[t]{5}{*}{ Spring } & April & Initial & $8.53 \pm 0.68$ & A & $36.62 \pm 1.30$ & A & $4.32 \pm 0.42$ & A & $12.37 \pm 1.45$ & A & $2.31 \pm 1.96$ \\
\hline & & $+\mathrm{Temp}+\mathrm{CO}_{2}$ & $19.43 \pm 5.06$ & a & $36.28 \pm 0.45$ & a & $1.71 \pm 0.18$ & a & $17.83 \pm 2.72$ & a & - \\
\hline & lune & +Temp & $19.26 \pm 3.41$ & a & $35.76 \pm 0.38$ & $a$ & $1.89 \pm 0.30$ & $a$ & $17.72 \pm 9.09$ & $a$ & - \\
\hline & 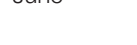 & $+\mathrm{CO}_{2}$ & $19.57 \pm 3.28$ & a & $36.28 \pm 0.73$ & a & $1.89 \pm 0.29$ & a & $21.18 \pm 3.55$ & a & - \\
\hline & & control & $20.88 \pm 0.21$ & a & $36.25 \pm 1.57$ & a & $1.74 \pm 0.09$ & a & $22.62 \pm 2.17$ & a & - \\
\hline \multirow[t]{5}{*}{ Summer } & July & Initial & $30.59 \pm 4.73$ & $B$ & $37.08 \pm 0.96$ & $A$ & $1.24 \pm 0.18$ & $B$ & $10.44 \pm 1.69$ & $\mathrm{~B}$ & - \\
\hline & & + Temp $+\mathrm{CO}_{2}$ & $\dagger$ & $\mathrm{a}$ & $\dagger$ & $\mathrm{a}$ & $\dagger$ & $\mathrm{a}$ & $\dagger$ & a & $\dagger$ \\
\hline & September & +Temp & $\dagger$ & a & $\dagger$ & a & $\dagger$ & $a$ & $\dagger$ & a & $\dagger$ \\
\hline & Sepretion & $+\mathrm{CO}_{2}$ & $34.75 \pm 8.03$ & $b$ & $36.64 \pm 1.26$ & $b$ & $1.09 \pm 0.24$ & $b$ & $14.12 \pm 0.67$ & $b$ & - \\
\hline & & control & $29.46 \pm 6.57$ & $b$ & $33.82 \pm 1.90$ & $b$ & $1.04 \pm 0.07$ & $b$ & $12.79 \pm 1.93$ & $b$ & - \\
\hline \multirow[t]{5}{*}{ Fall } & October & Initial & $30.31 \pm 4.68$ & $B$ & $35.46 \pm 0.72$ & $\mathrm{~B}$ & $1.20 \pm 0.19$ & $\mathrm{~B}$ & $11.55 \pm 1.59$ & $\mathrm{AB}$ & $9.60 \pm 2.93$ \\
\hline & & $+\mathrm{Temp}+\mathrm{CO}_{2}$ & $16.31 \pm 1.21$ & $\mathrm{a}$ & $33.07 \pm 0.88$ & $\mathrm{a}$ & $2.04 \pm 0.18$ & a & $4.98 \pm 2.56$ & a & - \\
\hline & December & +Temp & $17.63 \pm 0.24$ & a & $33.44 \pm 0.83$ & a & $1.90 \pm 0.02$ & a & $4.92 \pm 1.61$ & a & - \\
\hline & 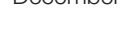 & $+\mathrm{CO}_{2}$ & $17.78 \pm 1.16$ & a & $34.08 \pm 0.66$ & a & $1.92 \pm 0.13$ & a & $4.98 \pm 1.03$ & a & - \\
\hline & & control & $18.17 \pm 2.71$ & a & $32.89 \pm 1.69$ & a & $1.85 \pm 0.35$ & a & $5.88 \pm 0.99$ & a & - \\
\hline \multirow[t]{5}{*}{ Winter } & January & Initial & $11.50 \pm 1.06$ & C & $33.89 \pm 0.87$ & C & $2.97 \pm 0.29$ & C & $7.41 \pm 1.51$ & C & - \\
\hline & & + Temp $+\mathrm{CO}_{2}$ & $13.39 \pm 1.32$ & $\mathrm{a}$ & $33.61 \pm 0.39$ & $\mathrm{a}$ & $2.53 \pm 0.26$ & a & $9.64 \pm 0.99$ & a & - \\
\hline & April & +Temp & $13.37 \pm 0.99$ & a & $33.90 \pm 1.03$ & a & $2.54 \pm 0.15$ & a & $9.64 \pm 0.57$ & a & - \\
\hline & April & $+\mathrm{CO}_{2}$ & $12.00 \pm 0.66$ & a & $33.77 \pm 0.41$ & $a$ & $2.82 \pm 0.12$ & $a$ & $10.97 \pm 0.99$ & $a b$ & - \\
\hline & & control & $13.15 \pm 2.76$ & a & $33.77 \pm 0.38$ & a & $2.64 \pm 0.52$ & a & $11.63 \pm 0.66$ & $b$ & - \\
\hline
\end{tabular}

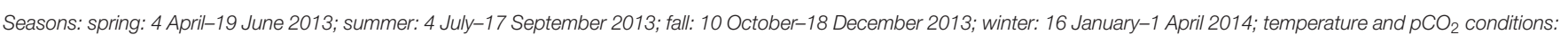

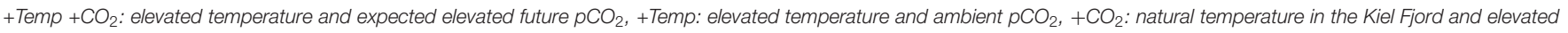

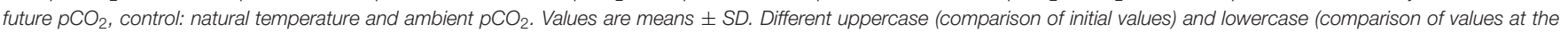

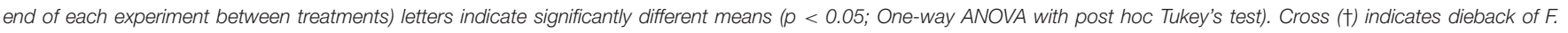
vesiculosus in the summer experiment under warming and minus (-) the absence of laminarin in the samples. 
the dieback of Fucus (One-way ANOVA with post hoc Tukey's test, $F=174.73, d f=3, p<0.001)$. Under increased $\mathrm{CO}_{2}$, F. vesiculosus accumulated $10 \%$ more mannitol compared to control conditions in summer, however this accumulation was not significant (Table 1). At the end of the fall experiment (December) similar low mannitol contents were measured in $F$. vesiculosus tips under all treatments. In the subsequent winter experiment warming decreased mannitol significantly by $20 \%$ (One-way ANOVA with post hoc Tukey's test, $F=4.39$, $d f=3$, $p<0.05$, Table $\mathbf{1}$ ).

Apices of naturally grown $F$. vesiculosus contained laminarin in spring of $2.3 \pm 1.96 \% \mathrm{DW}$ (April) and higher quantities in fall (October: $9.60 \pm 2.93 \% \mathrm{DW}$ ). Laminarin was neither detected in summer (July) and winter (January) in control plants from the field nor after growth in the Benthocosms in all seasons and treatments.

\section{DISCUSSION}

In coastal regions, river runoff, upwelling and biological activity modify the effects of atmospherically determined ocean acidification (Duarte et al., 2013) and many macroalgae are exposed to severe diurnal and seasonal fluctuations of the seawater carbonate concentration (Gao et al., 1991; Delille et al., 2000; Middelboe and Hansen, 2007). A special situation in the western Baltic Sea, and particularly in coastal bays such as the Kiel Fjord, are high and variable $\mathrm{pCO}_{2}$ values in surface waters with an annual mean of $\sim 800 \mathrm{ppm}$ and peak values of 2400 ppm during upwelling events (Thomsen et al., 2010, 2013; Melzner et al., 2013; Saderne et al., 2013). The need of marine algae to cope with these pronounced fluctuations in $\mathrm{CO}_{2}$ availability has probably promoted the evolution of effective carbon concentrating mechanisms (CCMs) (Giordano et al., 2005). F. vesiculosus possesses such a CCM (Surif and Raven, 1989), which is stimulated under carbon limitation, whereas elevated $\mathrm{pCO}_{2}$ conditions may down regulate $\mathrm{CCM}$ activity and thereby energy is saved (Johnston and Raven, 1990; Beardall and Giordano, 2002; Giordano et al., 2005; Wu et al., 2008) which may be invested into growth and/or reproduction.

In our study, we only observed a weak effect of enhanced $\mathrm{pCO}_{2}$ levels on growth of $F$. vesiculosus with only a slight increase of length and biomass growth and a stimulation of thallus tip formation (dichotomization) at elevated $\mathrm{pCO}_{2}$ treatments. The scarcity of significant effects of acidification on Fucus performance in this study may be due to Baltic Sea $F$. vesiculosus already being adapted to strongly fluctuating $\mathrm{pCO}_{2}$ and $\mathrm{pH}$ conditions in their native habitat (Thomsen et al., 2010, 2013; Melzner et al., 2013; Saderne et al., 2013). The biogenic circadian $\mathrm{pH}$ fluctuations in the Benthocosms were of similar amplitude as in local Fucus belts (Wahl et al., 2015c), which can exceed the predicted shift in mean $\mathrm{pH}$ until the year 2100 (Wootton et al., 2008; Saderne et al., 2013). In addition, F. vesiculosus possess an internal organic carbon pool which makes the algae even more independent of external $\mathrm{CO}_{2}$ fluctuations (Kawamitsu and Boyer, 1999). The interaction of acidification and warming (naturally as well as experimental) may weaken or cover the indicated beneficial effect of $\mathrm{pCO}_{2}$ on growth as photorespiration decreases with increasing $\mathrm{pCO}_{2}$ but increases with rising temperature (Sage and Kubien, 2007). This situation may be further complicated by the temperature requirements of the CCM enzymes (Shiraiwa and Miyachi, 1985; Wu et al., 2011).

Growth stimulation as a consequence of the down-regulation of the $\mathrm{CCM}$ at high $\mathrm{CO}_{2}$ and/or dissolved inorganic carbon (DIC) conditions has been proposed for macroalgae before (Nygård and Dring, 2008; Wu et al., 2008; Olischläger et al., 2012; Saderne, 2012; Koch et al., 2013). In contrast to our results, Gutow et al. (2014) found a reduced biomass growth of $F$. vesiculosus from the North Sea by about $10-15 \%$ at elevated $\mathrm{CO}_{2}$ levels (constant $700 \mathrm{ppm}$ ). It became however, apparent that different growth parameters (e.g., length, biomass, or dichotomization) do not respond synchronously and with the same rates to abiotic changes as was shown here and before (Knight and Parke, 1950). For example, in the spring experiment the three growth parameters did not show a uniform pattern as apical length and individual frond apices numbers of the Fucus thalli increased but biomass decreased (similarly as in Gutow et al., 2014) due to denudation of the wings of the lower part of the thalli combined with abscission of the receptacles after gamete release.

Several other abiotic factors, such as warming or nutrients may interact with growth under $\mathrm{CO}_{2}$ treatments as was also shown in the current Benthocosm experiments. Growth responses of $F$. vesiculosus to experimental warming were positive until May by providing optimal water temperatures for apical growth of $F$. vesiculosus (10-24 ${ }^{\circ} \mathrm{C}$, Graiff et al., 2015a). In contrast, in the first 2 weeks of the summer experiment (July) growth of $F$. vesiculosus under the warming treatment ceased when temperatures increased above $24^{\circ} \mathrm{C}$, a critical thermal threshold, which resulted in growth reductions when tested in a temperature gradient experiment (Graiff et al., 2015a). Apparently this thermal stress on growth was mitigated to some extent by increased $\mathrm{CO}_{2}$ resulting in higher and more constant growth rates in spring and early summer. The provision of increased amounts of DIC may have increasedantagonistically to warming-the performance of $F$. vesiculosus. This finding is consistent with Olischläger and Wiencke (2013) and Sarker et al. (2013), who examined the combined effects of $\mathrm{CO}_{2}$ and temperature on Neosiphonia harveyi and Chondrus crispus, respectively, and both found a release of the temperature stress response with increased $\mathrm{CO}_{2}$. During the further progression of the summer experiment however, when the Kiel Fjord water temperature exhibited a natural heat-wave (late July/August), water temperatures in the warming treatment reached temperatures between 27 and $30^{\circ} \mathrm{C}$ over 30 days (Table S3) which clearly exceeded the thermal tolerance of $F$. vesiculosus. Graiff et al. (2015a) showed that these temperatures already cause stress after 3 days and a reduction in growth rate after 7 days. This situation resulted in a dieback of the Fucus individuals and ephemeral fast-growing filamentous algae colonized the system (Werner et al., 2015). These results indicate that elevated $\mathrm{pCO}_{2}$ may mitigate sub-lethal temperature effects on $F$. vesiculosus to a limited extent but future ocean warming during summer heat-waves may probably not prevent local extinction and range shifts of F. vesiculosus (Wernberg et al., 2011; Jueterbock et al., 2013). 
Growth of macroalgae became enhanced under high $\mathrm{CO}_{2}$ as well due to an increased nitrate uptake and nitrate reductase enzyme activity which increased carbon retention in algal thalli under nitrogen saturation (Gordillo et al., 2001). This may explain the significant biomass increase but constant carbon and high nitrogen content of $F$. vesiculosus observed at the end of the winter experiment at elevated $\mathrm{pCO}_{2}$ and ambient temperature. At the beginning of the winter experiment (January) nitrate concentrations of the Kiel Fjord surface water were highest compared to all other months, but probably not saturating like under laboratory conditions. Nitrogen in F. vesiculosus follows the inorganic nitrogen concentration in the ambient water but often with a time lag. Nitrogen reserves which have been built up during the winter months were used for growth during AprilJune (Pedersen and Borum, 1996; Lehvo et al., 2001).

Other important biochemical compounds which are related to the annual growth cycle of Fucus are the storage products mannitol and laminarin and were also influenced by temperature and $\mathrm{CO}_{2}$ conditions as revealed here. Growth rates as well as mannitol concentration of $F$. vesiculosus in the Benthocosms were highest in spring/early summer when water temperature and solar irradiance increased naturually and were lowest in winter (December-January/February). Similar growth rates and mannitol concentrations of $F$. vesiculosus were measured in its native habitat showing comparable variations on a seasonal basis (Knight and Parke, 1950; Carlson, 1991; Lehvo et al., 2001; Wahl et al., 2010). In situ, F. vesiculosus only contained laminarin in spring and fall, but not in summer and winter. In all seasons considerable amounts of long-chained polysaccharides (e.g., fucoidans) were evident by LC-MS analysis. This may indicate a more important role of these polysaccharides for carbon storage in F. vesiculosus compared to laminarin which is the main storage carbohydrate in Laminaria sp. and Saccharina latissima (Black, 1950; Jensen and Haug, 1956). Any accumulation of storage compounds in the older basal thallus parts of $F$. vesiculosus (Küppers and Kremer, 1978), would have been missed here since we only analyzed the vegetative apices.

The risk of global warming for bio-engineering brown algae has been discussed in many recent publications worldwide (e.g., Wernberg et al., 2011; Harley et al., 2012; Wahl et al., 2015a). In the Baltic Sea, brown macroalgae are also at a risk to decrease in abundance or disappear over summer, however they may also benefit from a prolonged growth season in fall and winter due to "better" winter temperatures (Bartsch et al., 2012). Seasonal changes are already evident in the Baltic Sea as the duration of the growing season has increased, and the duration of the cold season has decreased (BACC II Author Team, 2015). Although the simulated warming increased temperatures from ambient $4-7$ to $8-12{ }^{\circ} \mathrm{C}$ (December to January) in our experiemnts and thereby elevated temperatures toward the optimum temperature range for growth of $F$. vesiculosus (Graiff et al., 2015a), in our fall and winter experiments we observed losses of biomass and apices as well as very low apical growth rates under the warming scenario. One explanation might be that $F$. vesiculosus is in a phase of "rest" in winter due to endogenously controlled growth rhythms which are synchronized with the annual change of environmental conditions such as photoperiod (Bäck et al., 1991;
Makarov et al., 1999). The combination of presumed winter light limitation (Rohde et al., 2008) and accelerated metabolism due to enhanced temperatures may have triggered an energy imbalance at elevated winter temperatures which resulted in worse overall growth performance as well as reduced mannitol concentrations compared to the ambient temperature treatment. Despite low winter growth rates $F$. vesiculosus had an overall vigorous habitus at control conditions. This might be explained by the ability of Fucus to down-regulate metabolism to dormancy for overwintering at low temperatures (Bäck et al., 1991; Kraufvelin et al., 2012), and reversely to up-regulate growth rapidly to a constant high rate under optimal temperature conditions (Graiff et al., 2015a).

Major effects of temperature and/or $\mathrm{CO}_{2}$ enrichment mostly became evident during the active growth phase of $F$. vesiculosus which was present in spring and early summer with up to threefold (warmed condition) and two-fold (ambient temperatures) higher growth rates under all treatments compared to the rest of the year (Figure 2). Nevertheless, the difference in length growth rates integrated over the whole course of each seasonal experiment was not significantly different between the different treatments, except for summer when the thermal threshold of $F$. vesiculosus was surpassed (Figure 3). Although the four seasonal experiments showed differential responses, the global annual response pattern could not be evaluated. A hypothetical global growth development over 1 year was visualized by summing up relative length, biomass and apex growth rates (Figure 4). It clearly becomes apparent that growth was enhanced throughout by increased $\mathrm{pCO}_{2}$ and ambient temperature conditions while warming either with or without enhanced $\mathrm{pCO}_{2}$ was worst for $F$. vesiculosus overall fitness (Figure 4). In the course of the spring experiment length growth seems to change from a slow steady increasing trend to a more stationary growth (ambient condition) or decrease (warmed condition), while net growth at the end of the season was very similar. This might be explained by the transition from vegetative to reproductive growth, as vegetative growth slowed down in the course of the spring experiment while receptacles matured. Vegetative growth and reproduction are mutually exclusive processes. Therefore, a switch between vegetative and reproductive growth is described as optimal resource allocation strategy (e.g., Cohen, 1971) which may be found also in morphologically complex brown algal species like F. vesiculosus or kelps (Bartsch et al., 2008). The transition from vegetative to reproductive growth is triggered in higher plants and also some brown algae by a sharply defined critical daylength (e.g., Lüning and tom Dieck, 1990; Araki, 2001). This is not yet known for F. vesiculosus although short photoperiods have been partially identified to trigger reproduction (Bäck et al., 1991).

Furthermore, our experiments indicate that photoperiod may be even more important in growth regulation than the seawater temperature, especially during spring and fall. This is indicated by stronger regressions between growth and photoperiod compared to temperature (Figure 2). The comparison of F. vesiculosus growth between the seasons depending on temperature revealed that apex elongation in fall and winter was between 0.72 and $1.40 \mathrm{~cm}$ (ambient temperature) or $0.63-1.62 \mathrm{~cm}$ (elevated temperature) and in spring $3.48-4.67 \mathrm{~cm}$ at comparable 


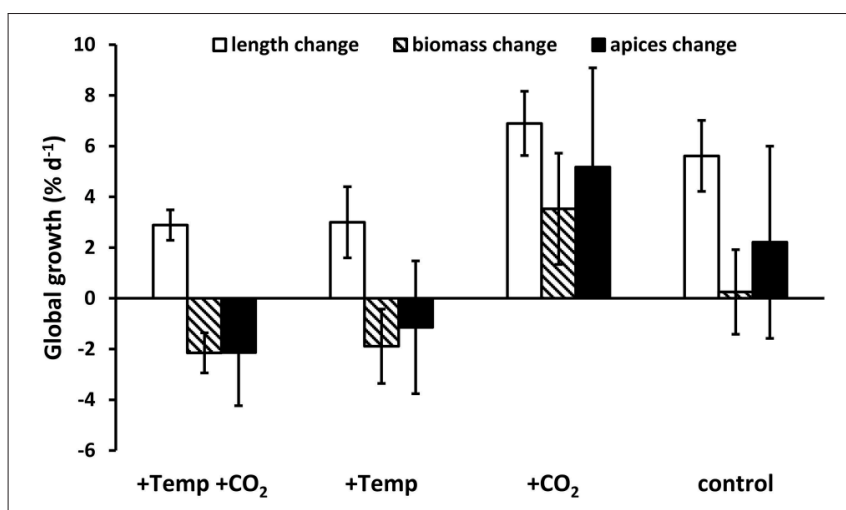

FIGURE 4 | Relative annual growth changes of length, biomass and individual frond apices numbers of Fucus vesiculosus summed up over all four seasonal experiments in four different treatment conditions of temperature and $\mathbf{p} \mathbf{C O}_{\mathbf{2}}$ in the Benthocosms. Temperature and $\mathrm{pCO}_{2}$ conditions: + Temp $+\mathrm{CO}_{2}$ : elevated temperature and expected elevated future $\mathrm{pCO}_{2}$, +Temp: elevated temperature and ambient $\mathrm{pCO}_{2},+\mathrm{CO}_{2}$ : natural temperature in the Kiel Fjord and elevated future $\mathrm{pCO}_{2}$, control: natural temperature and ambient $\mathrm{pCO}_{2}$. Mean of means $\pm \mathrm{SD}(n=3)$.

temperatures. This could indicate a day-length stimulus initiating growth after winter or the existence of a circannual rhythm previously determined in other brown algae (tom Dieck, 1991; Lüning and Kadel, 1993; Lüning, 1994; Schaffelke and Lüning, 1994; Makarov et al., 1995). Therefore, our results may indicate shifts from endogenous- to temperature-controlled growth of F. vesiculosus in the different seasons. We thereby assume that only if a critical day-length is reached or endogenous signals are apparent, other environmental factors such as increased solar irradiance, higher seawater temperatures or elevated $\mathrm{pCO}_{2}$ may further modulate growth and development of $F$. vesiculosus. In addition, photoperiod seems to have another important function for $F$. vesiculosus by providing increasing energy for growth and photosynthesis with increasing daylengths. Strömgren (1978) reported that growth of different Fucales was proportional to daylength. Similarly, we found that growth of F. vesiculosus was proportional to daylength under control conditions which was disrupted in the warming treatments.

Irradiance might further modulate the impact of the treatments on Fucus performance. It was previously reported that different levels of irradiance stimulate or weaken the effect of $\mathrm{CO}_{2}$ on different algal species (Zou and Gao, 2009; Sarker et al., 2013; Kübler and Dudgeon, 2015). However, in the Benthocosm experiments it was not possible to disentangle the modulating influences of light from e.g., nutrients or other factors. Therefore, manipulating photoperiod and measuring light intensity seems be a very important point for future experiments.

Interactions of ocean acidification and warming as well as the responses of multi-species assemblage are documented by several studies (Connell and Russell, 2010; Alsterberg et al., 2013; Eklöf et al., 2015; Queirós et al., 2015). In the study of Alsterberg et al. (2013) acidification in combination with warming had strong, positive direct and indirect effects on many components of the Zostera marina system in late summer (July-August).
Macroalgae, sediment-associated fauna, and Z. marina were all positively influenced by the combination of acidification and warming. However, this study (5 weeks during July and August 2010) did not examine the influence of season.

In particular, the competition of $F$. vesiculosus with fastgrowing filamentous epiphytes for light, nutrients and $\mathrm{CO}_{2}$ as well as the top-down control of mesograzers varied with season (Werner et al., 2015). For example, temperatures in the warming treatment at the end of the spring experiment slightly exceeded the optimum, and resulted in decreasing growth rates of $F$. vesiculosus. These sub-optimal temperatures may cause a reduction of net photosynthetic capacity due to elevated respiration (Andersen et al., 2013). However, these processes are not lethal per se, but seem to be costly over prolonged exposure times and may leave the organisms more susceptible to other stressors (Wernberg et al., 2010). In this period a strong overgrowth of the Fucus individuals with epiphytic ephemeral green algae developed until the end of the spring experiment (June) at elevated temperatures (Werner et al., 2015). For Baltic Sea $F$. vesiculosus rising temperatures $\left(>15^{\circ} \mathrm{C}\right)$ enhance biotic stress by increasing micro- and macro-fouling rates (Wahl et al., 2010), by increasing grazing rates of Idotea baltica and by decreasing levels of defense chemicals (Weinberger et al., 2011). Thus, decreasing growth, followed by strong epiphytism, leading to shading, thereby causing lowered mannitol concentrations, pigment loss (reddish tinge) and biomass loss of thalli may result from the additive or synergistic effects of abiotic and biotic stressors (Andersen et al., 2013; Woodin et al., 2013). The role of sub-lethal temperatures may thereby especially determine the outcome of competitive interactions and if climate change imposes multiple new stresses on a species, its tolerance limits might be surpassed. Accordingly, an accumulation of small effects acting in a non-linear manner could suddenly move toward a tipping point and major regime shifts could result (e.g., Harley et al., 2006, 2012) which are not foreseeable from uni-factorial or uni-species experiments.

Late summer turned out to be the critical season for temperature impacts on the entire Fucus system. Similarly, elevated water temperature may have caused substantial losses of S. latissima along the south coast of Norway (Andersen et al., 2013) by increased competition (e.g., for light) from filamentous epiphytes that have become more abundant over the last two to three decades. The frond of S. latissima is heavily fouled by epiphytes in summer, and preliminary results have shown that epiphytes may attenuate as much as $80-100 \%$ of the available light (Andersen et al., 2013) and also inhibit the re-establishment of the disturbed population (Andersen et al., 2011). In our system, epiphytes and ephemeral fast-growing filamentous algae showed massive growth in late summer, which may have accelerated temperature-induced die-off of F. vesiculosus. The epiphytic overgrowth could indirectly be explained by temperature-driven reduced top-down control, because the main mesograzer species (Idotea sp. and Gammarus sp.) in the Benthocosms declined under high temperature during summer as well (Werner et al., 2015). It can be suspected that in the shallow water zone ephemeral fast-growing and loose-lying algal species and/or thermophilic invasive algae will progressively 
take over (Kautsky et al., 1992; Korpinen et al., 2007; Weinberger et al., 2008). Fucus in the Baltic already lives close to its upper thermal tolerance limit and probably cannot cope with such increased average summer temperatures and increasing heatwave frequency. It hence may become a "loser" of global climate change (sensu Somero, 2010). Therefore, in addition to the already observed depth decline of F. vesiculosus in the Baltic Sea the adequate habitat of this ecological keystone species may further shrink and local extinctions can result. The observed changes in shallow water community structure would result in loss of ecosystem services and may have important ecological implications, since $F$. vesiculosus plays such a dominant role in hard bottom communities in the Baltic Sea, with consequences for many associated organisms (e.g., Wahl et al., 2015a).

Consequently, predicted changes in ocean acidification for the next century do not represent a major direct threat for the macroalga $F$. vesiculosus. Nonetheless, ocean acidification may influence organisms of the Fucus community due to speciesspecific differences in sensitivities to ocean acidification within the community (Fabricius et al., 2011; Hale et al., 2011). In conclusion it was shown that the single and combined responses of $F$. vesiculosus to elevated $\mathrm{pCO}_{2}$ and temperature in a near natural multi-species assemblage are complex. For the first time our study revealed that environmental warming and increased $\mathrm{CO}_{2}$ will exert differential effects on growth and metabolites depending on season and growth activity of plants. Warming and to a lesser extent increased $\mathrm{CO}_{2}$ affected $F$. vesiculosus growth in spring and early summer positively. In contrast, in late summer, fall and winter warming negatively influenced growth and metabolites of Fucus and growth enhancement under increased $\mathrm{CO}_{2}$ was only slight. Our results demonstrate that elevated $\mathrm{pCO}_{2}$ can affect growth of $F$. vesiculosus alone or interactively with warming. The response direction (additive, synergistic, or antagonistic) and intensity however varied with season and photoperiod. Thus, it is crucial to always consider the whole annual cycle of an alga or at least its different seasonal

\section{REFERENCES}

Alsterberg, C., Eklöf, J. S., Gamfeldt, L., Havenhand, J. N., and Sundbäck, K. (2013). Consumers mediate the effects of experimental ocean acidification and warming on primary producers. Proc. Natl. Acad. Sci. U.S.A. 110, 8603-8608. doi: $10.1073 /$ pnas. 1303797110

Andersen, G. S., Pedersen, M. F., and Nielsen, S. L. (2013). Temperature acclimation and heat tolerance of photosynthesis in Norwegian Saccharina latissima (Laminariales, Phaeophyceae). J. Phycol. 49, 689-700. doi: 10.1111/jpy.12077

Andersen, G. S., Steen, H., Christie, H., Fredriksen, S., and Moy, F. E. (2011). Seasonal patterns of sporophyte growth, fertility, fouling, and mortality of Saccharina latissima in Skagerrak, Norway: implications for forest recovery. J. Mar. Biol. 2011, 1-8. doi: 10.1155/2011/690375

Aneer, G., Florell, G., Kautsky, U., Nellbring, S., and Sjöstedt, L. (1983). In-situ observations of Baltic herring (Clupea harengus membras) spawning behaviour in the Askö-Landsort area, northern Baltic proper. Mar. Biol. 74, 105-110. doi: 10.1007/BF00413912

Araki, T. (2001). Transition from vegetative to reproductive phase. Curr. Opin. Plant Biol. 4, 63-68. doi: 10.1016/S.1369-5266(00)00137-0

Bäck, S., Collins, J. C., and Russell, G. (1991). Aspects of the reproductive biology of Fucus vesiculosus from the coast of SW Finland. Ophelia 34, 129-141. doi: 10.1080/00785326.1991.10429701 physiological states in order to be able to assess the full ecological implications of future climate change scenarios. The observed complexity of the responses and interactive effects between climate variables are consistent with results of other mesocosm experiments on seagrass (Alsterberg et al., 2013; Eklöf et al., 2015) and turf-forming alga (Connell and Russell, 2010). In conclusion, our study has added to the limited pool of long-term mesocosm experiments and contributes to growing evidence that ocean acidification in combination with warming will affect community composition of temperate macroalgae communities. The importance of evaluating the interactive impacts of multiple stressors (Folt et al., 1999; Darling and Côté, 2008) in the context of seasonally fluctuating environmental conditions which alter and control the physiological responses of macroalgae is emphasized by our study.

\section{ACKNOWLEDGMENTS}

We gratefully thank Björn Buchholz for the maintenance of the Benthocosms, Lars Gutow for helpful comments in planning the sampling procedures and Romina Bläsner, Jascha Berberich, Juliane Müller, and Henrike Pfefferkorn for their support during sampling and their invaluable help in the laboratory. We also gratefully acknowledge all members of the BIOACID Phase II consortium "Benthic assemblages" for their cooperation and support. We thank the reviewers for their helpful suggestions. This research was funded by the Project BIOACID Phase II of the German Federal Ministry of Education and Research (BMBF; FKZ 03F0655L).

\section{SUPPLEMENTARY MATERIAL}

The Supplementary Material for this article can be found online at: http://journal.frontiersin.org/article/10.3389/fmars. 2015.00112

BACC II Author Team (2015). Second Assessment of Climate Change for the Baltic Sea Basin. Gesthacht: Springer International Publishing AG.

Badger, M. (2003). The roles of carbonic anhydrases in photosynthetic $\mathrm{CO}_{2}$ concentrating mechanisms. Photosynth. Res. 77, 83-94. doi: 10.1023/A:1025821717773

Bartsch, I., Vogt, J., Pehlke, C., and Hanelt, D. (2013). Prevailing sea surface temperatures inhibit summer reproduction of the kelp Laminaria digitata at Helgoland (North Sea). J. Phycol. 49, 1061-1073. doi: 10.1111/jpy. 12125

Bartsch, I., Wiencke, C., and Laepple, T. (2012). "Global seaweed biogeography under a changing climate: the prospected effects of temperature," in Seaweed Biology, eds C. Wiencke and K. Bischof (Berlin Heidelberg: Springer-Verlag), 383-406.

Bartsch, I., Wiencke, C., Bischof, K., Buchholz, C. M., Buck, B. H., Eggert, A., et al. (2008). The genus Laminaria sensu lato?: recent insights and developments. Eur. J. Phycol. 43, 1-86. doi: 10.1080/096702607017 11376

Beardall, J., and Giordano, M. (2002). Ecological implications of microalgal and cyanobacterial $\mathrm{CO}_{2}$ concentrating mechanisms, and their regulation. Funct. Plant Biol. 29, 335-347. doi: 10.1071/PP01195

Beardall, J., Beer, S., and Raven, J. A. (1998). Biodiversity of marine plants in an era of climate change: some predictions based on physiological performance. Bot. Mar. 41, 113-123. doi: 10.1515/botm.1998.41.1-6.113 
Berger, R., Bergström, L., Gran, E., and Kautsky, L. (2004). How does eutrophication affect different life stages of Fucus vesiculosus in the Baltic Sea? - a conceptual model. Hydrobiologia 514, 243-248. doi: 10.1023/B:hydr.0000018222.44511.b7

Bindoff, N. L., Willebrand, J., Artale, V., Cazenave, A., et al. (2007). “Observations: oceanic climate change and sea level," in Climate Change 2007: The Physical Science Basis. Contribution of Working Group I to the Fourth Assessment Report of the Intergovernmental Panel on Climate Change, eds S. Solomon, D. Qin, M. Manning, Z. Chen, M. Marquis, K. B. Averyt, M. Tignor, and H. L. Miller (Cambridge: Cambridge University Press), 129-234.

Black, W. A. P. (1950). The seasonal variation in weight and chemical composition of the common British Laminariaceae. J. Mar. Biol. Assoc. U.K. 29, 45-72. doi: $10.1017 /$ S0025315400056186

Brown, C. J., Saunders, M. I., Possingham, H. P., and Richardson, A. J. (2013). Managing for interactions between local and global stressors of ecosystems. PLoS ONE 8:e65765. doi: 10.1371/journal.pone.0065765

Bruno, J. F., Stachowicz, J. J., and Bertness, M. D. (2003). Incorporating facilitation into ecological theory. Trends Ecol. Evol. 18, 119-125. doi: 10.1016/S01695347(02)00045-9

Caldeira, K., and Wickett, M. E. (2005). Ocean model predictions of chemistry changes from carbon dioxide emissions to the atmosphere and ocean. J. Geophys. Res. 110, 1-12. doi: 10.1029/2004jc002671

Carlson, L. (1991). Seasonal variation in growth, reproduction and nitrogen content of Fucus vesiculosus L. in the Öresund, Southern Sweden. Bot. Mar. 34, 447-453. doi: 10.1515/botm.1991.34.5.447

Cohen, D. (1971). Maximizing final yield when growth is limited by time or by limiting resources. J. Theor. Biol. 33, 299-307. doi: 10.1016/00225193(71)90068-3

Coleman, M. A., and Kelaher, B. P. (2009). Connectivity among fragmented populations of a habitat-forming alga, Phyllospora comosa (Phaeophyceae, Fucales) on an urbanised coast. Mar. Ecol. Prog. Ser. 381, 63-70. doi: 10.3354/meps07977

Coleman, M. A., Chambers, J., Knott, N. A., Malcolm, H. A., Harasti, D., Jordan, A., et al. (2011). Connectivity within and among a network of temperate marine reserves. PLoS ONE 6:e20168. doi: 10.1371/journal.pone.0020168

Connell, S. D., and Russell, B. D. (2010). The direct effects of increasing $\mathrm{CO}_{2}$ and temperature on non-calcifying organisms: increasing the potential for phase shifts in kelp forests. Proc. Biol. Soc. 277, 1409-1415. doi: 10.1098/rspb.2009.2069

Darling, E. S., and Côté, I. M. (2008). Quantifying the evidence for ecological synergies. Ecol. Lett. 11, 1278-1286. doi: 10.1111/j.1461-0248.2008.01243.x

Davison, I. R., and Pearson, G. A. (1996). Stress tolerance in intertidal seaweeds. J. Phycol. 32, 197-211. doi: 10.1111/j.0022-3646.1996.00197.x

Davison, I. R., Greene, R. M., and Podolak, E. J. (1991). Temperature acclimation of respiration and photosynthesis in the brown alga Laminaria saccharina. Mar. Biol. 110, 449-454. doi: 10.1007/BF01344363

Delille, B., Delille, D., Fiala, M., Prevost, C., and Frankignoulle, M. (2000). Seasonal changes of $\mathrm{pCO}_{2}$ over a subantarctic Macrocystis kelp bed. Polar Biol. 23, 706-716. doi: 10.1007/s003000000142

Dickson, A. G., Sabine, C. L., and Christian, J. R. (2007). Guide to Best Practices for Ocean CO2 Measurements. Sidney, BC: PICES Special Publications.

Diffenbaugh, N. S., Pal, J. S., Trapp, R. J., and Giorgi, F. (2005). Fine-scale processes regulate the response of extreme events to global climate change. Proc. Natl. Acad. Sci. U. S. A. 102, 15774-15778. doi: 10.1073/pnas.0506 042102

Duarte, C. M., Hendriks, I. E., Moore, T. S., Olsen, Y. S., Steckbauer, A., Ramajo, L., et al. (2013). Is ocean acidification an open-ocean syndrome? Understanding anthropogenic impacts on seawater pH. Estuaries Coasts 36, 221-236. doi: 10.1007/s12237-013-9594-3

Eggert, A., Visser, R. J. W., Van Hasselt, P. R., and Breeman, A. M. (2006). Differences in acclimation potential of photosynthesis in seven isolates of the tropical to warm temperate macrophyte Valonia utricularis (Chlorophyta). Phycologia 45, 546-556. doi: 10.2216/05-03.1

Eklöf, J. S., Havenhand, J. N., Alsterberg, C., and Gamfeldt, L. (2015). Communitylevel effects of rapid experimental warming and consumer loss outweigh effects of rapid ocean acidification. Oikos 124, 1040-1049. doi: 10.1111/oik.01544

Elken, J., Lehmann, A., and Myrberg, K. (2015). "Recent change-marine circulation and stratification," in Second Assessment of Climate Change for the
Baltic Sea Basin, eds H.-J. Bolle, M. Menenti and S. I. Rasool (Gesthacht: Springer International Publishing AG Switzerland), 131-144.

Fabricius, K. E., Langdon, C., Uthicke, S., et al. (2011). Losers and winners in coral reefs acclimatized to elevated carbon dioxide concentrations. Nat. Clim. Change 1, 165-169. doi: 10.1038/nclimate1122

Feely, R. A., Sabine, C. L., Lee, K., Berelson, W., Kleypas, J., Fabry, V. J., et al. (2004). Impact of anthropogenic $\mathrm{CO}_{2}$ on the $\mathrm{CaCO}_{3}$ system in the oceans. Science 305, 362-366. doi: 10.1126/science.1097329

Folt, C. L., Chen, C. Y., Moore, M. V., and Burnaford, J. (1999). Synergism and antagonism among multiple stressors. Limnol. Oceanogr. 44, 864-877. doi: 10.4319/lo.1999.44.3_part_2.0864

Gao, K., Aruga, Y., Asada, K., Toshiaki, I., Akano, T., and Kiyohara, M. (1991). Enhanced growth of the red alga Porphyra yezoensis Ueda in high $\mathrm{CO}_{2}$ concentrations. J. Appl. Phycol. 3, 355-362. doi: 10.1007/BF02392889

Giordano, M., Beardall, J., and Raven, J. A. (2005). $\mathrm{CO}_{2}$ concentrating mechanisms in algae: mechanisms, environmental modulation, and evolution. Annu. Rev. Plant Biol. 56, 99-131. doi: 10.1146/annurev.arplant.56.032604.144052

Gordillo, F. J. L., Jiménez, C., Goutx, M., and Niell, X. (2001). Effects of $\mathrm{CO}_{2}$ and nitrogen supply on the biochemical composition of Ulva rigida with especial emphasis on lipid class analysis. J. Plant Physiol. 158, 367-373. doi: 10.1078/0176-1617-00209

Graiff, A., Liesner, D., Karsten, U., and Bartsch, I. (2015a). Temperature tolerance of western Baltic Sea Fucus vesiculosus - growth, photosynthesis and survival. J. Exp. Mar. Bio. Ecol. 471, 8-16. doi: 10.1016/j.jembe.2015.05.009

Graiff, A., Ruth, W., Kragl, U., and Karsten, U. (2015b). Chemical characterization and quantification of the brown algal storage compound laminarin-A new methodological approach. J. Appl. Phycol. doi: 10.1007/s10811-015-0563-z

Gräwe, U., Friedland, R., and Burchard, H. (2013). The future of the western Baltic Sea: two possible scenarios. Ocean Dyn. 63, 901-921. doi: 10.1007/s10236-0130634-0

Gutow, L., Rahman, M. M., Bartl, K., Saborowski, R., Bartsch, I., and Wiencke, C. (2014). Ocean acidification affects growth but not nutritional quality of the seaweed Fucus vesiculusos (Phaeophyceae, Fucales). J. Exp. Mar. Bio. Ecol. 453, 84-90. doi: 10.1016/j.jembe.2014.01.005

Haage, P. (1975). Quantitative Investigations of the Baltic Fucus Belt Macrofauna. 2. Quantitative Seasonal Fluctuations. 9. Contrib. Stockholm: Askö. Lab., Stockholm University.

Haage, P. (1976). Quantitative Investigations of the Baltic Fucus Belt Macrofauna. 3. Seasonal Variation in Biomass, Reproduction and Population Dynamics of the Dominant Taxa. 10. Contrib. Stockholm: Askö. Lab., Stockholm University.

Hale, R., Calosi, P., McNeill, L., Mieszkowska, N., and Widdicombe, S. (2011) Predicted levels of future ocean acidification and temperature rise could alter community structure and biodiversity in marine benthic communities. Oikos 120, 661-674. doi: 10.1111/j.1600-0706.2010.19469.x

Halpern, B. S., Silliman, B. R., Olden, J. D., Bruno, J. P., and Bertness, M. D. (2007). Incorporating positive interactions in aquatic restoration and conservation. Front. Ecol. Environ. 5, 153-160. doi: 10.1890/15409295(2007)5[153:IPIIAR]2.0.CO;2

Harley, C. D. G., Anderson, K. M., Demes, K. W., Jorve, J. P., Kordas, R. L., Coyle, T. A., et al. (2012). Effects of climate change on global seaweed communities J. Phycol. 48, 1064-1078. doi: 10.1111/j.1529-8817.2012.01224.x

Harley, C. D. G., Randall Hughes, A., Hultgren, K. M., Miner, B. G., Sorte, C. J. B., Thornber, C. S., et al. (2006). The impacts of climate change in coastal marine systems. Ecol. Lett. 9, 228-241. doi: 10.1111/j.1461-0248.2005.00871.x

HELCOM (2013). "Climate change in the Baltic Sea area. HELCOM thematic assessment in 2013," in Baltic Sea Environment Proceedings No. 137. (Helsinki).

Hepburn, C. D., Pritchard, D. W., Cornwall, C. E., McLeod, R. J., Beardall, J., Raven, J. A., et al. (2011). Diversity of carbon use strategies in a kelp forest community: Implications for a high $\mathrm{CO}_{2}$ ocean. Glob. Chang. Biol. 17, 2488-2497. doi: 10.1111/j.1365-2486.2011.02411.x

Holmlund, M. B., Peterson, C. H., and Hay, M. E. (1990). Does algal morphology affect amphipod susceptibility to fish predation? J. Exp. Mar. Bio. Ecol. 139, 65-83. doi: 10.1016/0022-0981(90)90039-F

Jensen, A., and Haug, A. (1956). Geographical and seasonal variation in the chemical composition of Laminaria hyperborea and Laminaria digitata from the Norwegian coast. Rep. Norw. Inst. Seaweed Res. 14, 1-8

Johnson, K. M., Wills, K. D., Butler, D. B., Johnson, W. K., and Wong, C. S. (1993). Coulometric total carbon dioxide analysis for marine studies: 
maximizing the performance of an automated gas extraction system and coulometric detector. Mar. Chem. 44, 167-187. doi: 10.1016/0304-4203(93) 90201-X

Johnston, A. M., and Raven, J. A. (1990). Effects of culture in high $\mathrm{CO}_{2}$ on the photosynthetic physiology of Fucus serratus. Eur. J. Phycol. 25, 75-82. doi: 10.1080/00071619000650071

Jueterbock, A., Tyberghein, L., Verbruggen, H., Coyer, J. A., Olsen, J. L., and Hoarau, G. (2013). Climate change impact on seaweed meadow distribution in the North Atlantic rocky intertidal. Ecol. Evol. 3, 1356-1373. doi: 10.1002/ece 3.541

Karsten, U., Thomas, D. M., Weykam, G., Daniel, C., and Kirst, G. O. (1991). A simple and rapid method for extraction and separation of low molecular weight of carbohydrates from marine macroalgae using high performance liquid chromatography. Plant Physiol. Biochem. 29, 373-378.

Kautsky, H., and van der Maarel, E. (1990). Multivariate approaches to the variation in phytobenthic communities and environmental vectors in the Baltic Sea. Mar. Ecol. Prog. Ser. 60, 169-184. doi: 10.3354/meps060169

Kautsky, H., Kautsky, L., Kautsky, N., Kautsky, U., and Lindblad, C. (1992). "Studies on the Fucus vesiculosus community in the Baltic Sea," in Phycological Studies of Nordic Coastal Waters-Acta Phytogeogr. Suec. 78, eds I. Wallentinus and P. Snoeijs (Uppsala: OPULUS Press AB), 33-48.

Kautsky, L., and Kautsky, H. (1989). Algal species diversity and dominance along gradients of stress and disturbance in marine environments. Vegetatio 83, 259-267. doi: 10.1007/BF00031698

Kautsky, N., Kautsky, H., Kautsky, U., and Waern, M. (1986). Decreased depth penetration of Fucus vesiculosus (L.) since the 1940's indicates eutrophication of the Baltic Sea. Mar. Ecol. Prog. Ser. 28, 1-8. doi: 10.3354/meps 028001

Kawamitsu, Y., and Boyer, J. S. (1999). Photosynthesis and carbon storage between tides in a brown alga, Fucus vesiculosus. Mar. Biol. 133, 361-369. doi: $10.1007 / \mathrm{s} 002270050475$

Kingsolver, J. G., and Huey, R. B. (1998). Evolutionary analyses of morphological and physiological plasticity in thermally variable environments. Am. Zool. 545, 1-15. doi: 10.1093/icb/38.3.545

Knight, M., and Parke, M. (1950). A biological study of Fucus vesiculosus L. and F. serratus L. J. Mar. Biol. Assoc. U.K. 29, 439-501. doi: 10.1017/S0025315400055454

Koch, M., Bowes, G., Ross, C., and Zhang, X.-H. (2013). Climate change and ocean acidification effects on seagrasses and marine macroalgae. Glob. Chang. Biol. 19, 103-132. doi: 10.1111/j.1365-2486.2012.02791.x

Korpinen, S., Honkanen, T., Vesakoski, O., Hemmi, A., Koivikko, R., Loponen, J., et al. (2007). Macroalgal communities face the challenge of changing biotic interactions: review with focus on the Baltic Sea. Ambio 36, 203-211. doi: 10.1579/0044-7447(2007)36[203:MCFTCO]2.0.CO;2

Kraufvelin, P., Ruuskanen, A. T., Bäck, S., and Russell, G. (2012). Increased seawater temperature and light during early springs accelerate receptacle growth of Fucus vesiculosus in the northern Baltic proper. Mar. Biol. 159, 1795-1807. doi: 10.1007/s00227-012-1970-1

Kroeker, K. J., Kordas, R. L., Crim, R. N., and Singh, G. G. (2010). Metaanalysis reveals negative yet variable effects of ocean acidification on marine organisms. Ecol. Lett. 13, 1419-1434. doi: 10.1111/j.1461-0248.2010. 01518.x

Kroeker, K. J., Kordas, R. L., Crim, R., Hendriks, I. E., Ramajo, L., Singh, G. S., et al. (2013). Impacts of ocean acidification on marine organisms: quantifying sensitivities and interaction with warming. Glob. Chang. Biol. 19, 1884-1896. doi: $10.1111 /$ gcb. 12179

Kübler, J. E., and Davison, I. R. (1995). Thermal acclimation of light-use characteristics of Chondrus crispus (Rhodophyta). Eur. J. Phycol. 30, 189-195. doi: 10.1080/09670269500650971

Kübler, J. E., and Dudgeon, S. R. (2015). Predicting effects of ocean acidification and warming on algae lacking carbon concentrating mechanisms. PLoS ONE 10:e132806. doi: 10.1371/journal.pone.0132806

Küppers, U., and Kremer, B. P. (1978). Longitudinal profiles of carbon dioxide fixation capacities in marine macroalgae. Plant Physiol. 62, 49-53. doi: 10.1104/pp.62.1.49

Lehvo, A., and Bäck, S. (2001). Survey of macroalgal mats in the Gulf of Finland, Baltic Sea. Aquat. Conserv. Mar. Freshw. Ecosyst. 11, 11-18. doi: $10.1002 /$ aqc. 428
Lehvo, A., Bäck, S., and Kiirikki, M. (2001). Growth of Fucus vesiculosus L. (Phaeophyta) in the Northern baltic proper: energy and nitrogen storage in seasonal environment. Bot. Mar. 44, 345-350. doi: 10.1515/BOT.2001.044

Lotze, H. K., and Schramm, W. (2000). Ecophysiological traits explain species dominance patterns in macroalgal blooms. J. Phycol. 36, 287-295. doi: 10.1046/j.1529-8817.2000.99109.x

Lotze, H. K., Lenihan, H. S., Bourque, B. J., Bradbury, R. H., Cooke, R. G., Kay, M. C., et al. (2006). Depletion, degradation, and recovery potential of estuaries and coastal seas. Science 312, 1806-1809. doi: 10.1126/science.1128035

Lüning, K. (1990). Seaweeds: Their Environment, Biogeography and Ecophysiology. New York, NY: John Wiley and Sons, Inc.

Lüning, K. (1994). Circadian growth rhythm in juvenile sporophytes of Laminariales (Phaeophyta). J. Phycol. 30, 193-199. doi: 10.1111/j.00223646.1994.00193.x

Lüning, K., and Kadel, P. (1993). Daylength range for circannual rhythmicity in Pterygophora californica (Alariaceae, Phaeophyta) and synchronization of seasonal growth by daylength cycles in several other brown algae. Phycologia 32, 379-387. doi: 10.2216/i0031-8884-32-5-379.1

Lüning, K., and tom Dieck, I. (1990). "The distribution and evolution of the Laminariales: North Pacific-Atlantic relationships," in Evolutionary Biogeography of the Marine Algae of the North Atlantic, eds D. J. Garbary and G. R. South (Berlin Heidelberg: Springer-Verlag), 187-204.

MacKenzie, B. R., and Schiedek, D. (2007). Daily ocean monitoring since the 1860s shows record warming of northern European seas. Glob. Chang. Biol. 13, 1335-1347. doi: 10.1111/j.1365-2486.2007.01360.x

Makarov, V. N., Makarov, M. V., and Schoschina, E. V. (1999). Seasonal dynamics of growth in the Barents Sea seaweeds: endogenous and exogenous regulation. Bot. Mar. 42, 43-49. doi: 10.1515/BOT.1999.007

Makarov, V. N., Schoschina, E. V., and Lüning, K. (1995). Diurnal and circadian periodicity of mitosis and growth in marine macroalgae. I. Juvenile sporophytes of Laminariales (Phaeophyta). Eur. J. Phycol. 30, 261-266. doi: 10.1080/09670269500651031

Meehl, G. A., and Tebaldi, C. (2004). More intense, more frequent, and longer lasting heat waves in the 21st century. Science 305, 994-997. doi: 10.1126/science. 1098704

Melzner, F., Thomsen, J., Koeve, W., Oschlies, A., Gutowska, M. A., Bange, H. W. et al. (2013). Future ocean acidification will be amplified by hypoxia in coastal habitats. Mar. Biol. 160, 1875-1888. doi: 10.1007/s00227-012-1954-1

Middelboe, A. L., and Hansen, P. J. (2007). High pH in shallow-water macroalgal habitats. Mar. Ecol. Prog. Ser. 338, 107-117. doi: 10.3354/meps338107

Middelboe, A. L., Sand-Jensen, K., and Binzer, T. (2006). Highly predictable photosynthetic production in natural macroalgal communities from incoming and absorbed light. Oecologia 150, 464-476. doi: 10.1007/s00442-006-0526-9

Müller, R., Laepple, T., Bartsch, I., and Wiencke, C. (2009). Impact of oceanic warming on the distribution of seaweeds in polar and cold-temperate waters. Bot. Mar. 52, 617-638. doi: 10.1515/BOT.2009.080

Nygård, C. A., and Dring, M. J. (2008). Influence of salinity, temperature, dissolved inorganic carbon and nutrient concentration on the photosynthesis and growth of Fucus vesiculosus from the Baltic and Irish Seas. Eur. J. Phycol. 43, 253-262. doi: 10.1080/09670260802172627

Olischläger, M., and Wiencke, C. (2013). Ocean acidification alleviates lowtemperature effects on growth and photosynthesis of the red alga Neosiphonia harveyi (Rhodophyta). J. Exp. Bot. 64, 5587-5597. doi: 10.1093/jxb/ert329

Olischläger, M., Bartsch, I., Gutow, L., and Wiencke, C. (2012). Effects of ocean acidification on different life-cycle stages of the kelp Laminaria hyperborea (Phaeophyceae). Bot. Mar. 55, 511-525. doi: 10.1515/bot-2012-0163

Orr, J. C., Fabry, V. J., Aumont, O., Bopp, L., Doney, S. C., Feely, R. A., et al. (2005). Anthropogenic ocean acidification over the twenty-first century and its impact on calcifying organisms. Nature 437, 681-686. doi: 10.1038/nature04095

Pedersen, M. F., and Borum, J. (1996). Nutrient control of algal growth in estuarine waters. Nutrient limitation and the importance of nitrogen requirements and nitrogen storage among phytoplankton and species of macroalgae. Mar. Ecol. Prog. Ser. 142, 261-272. doi: 10.3354/meps142261

Pierrot, D., Lewis, E., and Wallace, D. W. R. (2006). "MS Excel program developed for CO2 system calculations," in ORNL/CDIAC-105a. ed. Oak Ridge National Laboratory, US Department of Energy (Tennessee: Oak Ridge).

Queirós, A. M., Fernandes, J. A., Faulwetter, S., Nunes, J., Rastrick, S. P. S., Mieszkowska, N., et al. (2015). Scaling up experimental ocean acidification and 
warming research: From individuals to the ecosystem. Glob. Chang. Biol. 21, 130-143. doi: $10.1111 / \mathrm{gcb} .12675$

R. Development Core Team (2014). R: A Language and Environment for Statistical Computing. R Foundation for Statistical Computing, Vienna. Available online at: http://www.R-project.org/

Raven, J. (1997). Putting the C in phycology. Eur. J. Phycol. 32, 319-333. doi: 10.1080/09670269710001737259

Raven, J. A., Giordano, M., Beardall, J., and Maberly, S. C. (2011). Algal and aquatic plant carbon concentrating mechanisms in relation to environmental change. Photosynth. Res. 109, 281-296. doi: 10.1007/s11120-011-9632-6

Raven, J., Caldera, K., Elderfield, H., Hoegh-Guldberg, O., Liss, P., Riebesell, U., et al. (2005). Ocean Acidification due to Increasing Atmospheric Carbon dioxide. Cardiff, UK: The Royal Society.

Rickert, E., Karsten, U., Pohnert, G., and Wahl, M. (2015). Seasonal fluctuations in chemical defenses against macrofouling in Fucus vesiculosus and Fucus serratus from the Baltic Sea. Biofouling 31, 363-377. doi: 10.1080/08927014.2015.1041020

Rohde, S., and Wahl, M. (2008). Temporal dynamics of induced resistance in a marine macroalga: time lag of induction and reduction in Fucus vesiculosus. J. Exp. Mar. Bio. Ecol. 367, 227-229. doi: 10.1016/j.jembe.2008.10.003

Rohde, S., Hiebenthal, C., Wahl, M., Karez, R., and Bischof, K. (2008). Decreased depth distribution of Fucus vesiculosus (Phaeophyceae) in the Western Baltic: effects of light deficiency and epibionts on growth and photosynthesis. Eur. J. Phycol. 43, 143-150. doi: 10.1080/09670260801901018

Rönnbäck, P., Kautsky, N., Pihl, L., Troell, M., Söderqvist, T., and Wennhage, H. (2007). Ecosystem goods and services from Swedish coastal habitats: identification, valuation, and implications of ecosystem shifts. AMBIO A. J. Hum. Environ. 36, 534-544. doi: 10.1579/0044-7447(2007)36[534:EGASFS]2.0.CO;2

Roth, O., Kurtz, J., and Reusch, T. B. H. (2010). A summer heat wave decreases the immunocompetence of the mesograzer, Idotea baltica. Mar. Biol. 157, 1605-1611. doi: 10.1007/s00227-010-1433-5

Russell, B. D., Passarelli, C. A., and Connell, S. D. (2011). Forecasted $\mathrm{CO}_{2}$ modifies the influence of light in shaping subtidal habitat. J. Phycol. 47, 744-752. doi: 10.1111/j.1529-8817.2011.01002.x

Russell, B. D., Thompson, J. A. I., Falkenberg, L. J., and Connell, S. D. (2009). Synergistic effects of climate change and local stressors: $\mathrm{CO}_{2}$ and nutrientdriven change in subtidal rocky habitats. Glob. Chang. Biol. 15, 2153-2162. doi: 10.1111/j.1365-2486.2009.01886.x

Sabine, C. L., Feely, R. A., Gruber, N., Key, R. M., Lee, K., Bullister, J. L., et al. (2004). The oceanic sink for anthropogenic CO2. Science 305, 367-371. doi: $10.1126 /$ science. 1097403

Saderne, V. (2012). The Ecological Effect of CO2 on the Brown Algae Fucus serratus and its Epibionts: From the Habitat to the Organismic Scale. Ph.D. thesis, Christian-Albrechts-Universität Kiel, Kiel.

Saderne, V., Fietzek, P., and Herman, P. M. J. (2013). Extreme variations of $\mathrm{pCO}_{2}$ and $\mathrm{pH}$ in a macrophyte meadow of the Baltic Sea in summer: evidence of the effect of photosynthesis and local upwelling. PLOS ONE 8:e62689. doi: 10.1371/journal.pone.0062689

Sage, R. F., and Kubien, D. S. (2007). The temperature response of $C_{3}$ and $\mathrm{C}_{4}$ photosynthesis. Plant Cell Environ. 30, 1086-1106. doi: 10.1111/j.13653040.2007.01682.X

Sarker, M. Y., Bartsch, I., Olischläger, M., Gutow, L., and Wiencke, C. (2013). Combined effects of $\mathrm{CO}_{2}$, temperature, irradiance and time on the physiological performance of Chondrus crispus (Rhodophyta). Bot. Mar. 56, 63-74. doi: 10.1515/bot-2012-0143

Schaffelke, B., and Lüning, K. (1994). A circannual rhythm controls seasonal growth in the kelps Laminaria hyperborea and L. digitata from Helgoland (North Sea). Eur. J. Phycol. 29, 49-56. doi: 10.1080/096702694006 50471

Shiraiwa, Y., and Miyachi, S. (1985). Effects of temperature and CO2 concentration on induction of carbonic anhydrase and changes in efficiency of photosynthesis in Chlorella vulgaris 11h. Plant Cell Physiol. 26, 543-549.

Somero, G. N. (2010). The physiology of climate change: how potentials for acclimatization and genetic adaptation will determine "winners" and "losers." J. Exp. Biol. 213, 912-920. doi: 10.1242/jeb.037473

Strömgren, T. (1978). The effect of photoperiod on the length growth of five species of intertidal Fucales. Sarsia 63, 155-157.
Surif, M. B., and Raven, J. A. (1989). Exogenous inorganic carbon sources for photosynthesis in seawater by members of the Fucales and the Laminariales (Phaeophyta): ecological and taxonomic implications. Oecologia 78, 97-105. doi: 10.1007/BF00377203

Thomsen, J., Casties, I., Pansch, C., Körtzinger, A., and Melzner, F. (2013). Food availability outweighs ocean acidification effects in juvenile Mytilus edulis: laboratory and field experiments. Glob. Chang. Biol. 19, 1017-1027. doi: 10.1111/gcb.12109

Thomsen, J., Gutowska, M. A., Saphörster, J., Heinemann, A., Trübenbach, K., Fietzke, J., et al. (2010). Calcifying invertebrates succeed in a naturally $\mathrm{CO}_{2}$ rich coastal habitat but are threatened by high levels of future acidification. Biogeosciences 7, 3879-3891. doi: 10.5194/bg-7-3879-2010

tom Dieck, I. (1991). Circannual growth rhythm and photoperiodic sorus induction in the kelp Laminaria setchelli (Phaeophyta). J. Phycol. 27, 341-350 doi: 10.1111/j.0022-3646.1991.00341.x

Torn, K., Krause-Jensen, D., and Martin, G. (2006). Present and past depth distribution of bladderwrack (Fucus vesiculosus) in the Baltic Sea. Aquat. Bot. 84, 53-62. doi: 10.1016/j.aquabot.2005.07.011

Vasseur, D. A., Delong, J. P., Gilbert, B., Greig, H. S., Harley, C. D. G., McCann, K. S., et al. (2014). Increased temperature variation poses a greater risk to species than climate warming. Proc. Biol. Soc. 281, 1-8. doi: 10.1098/rspb.2013.2612

Verardo, D. J., Froehlich, P. N., and McIntyre, A. (1990). Determination of organic carbon and nitrogen in marine sediments using Carlo Erba NA-1500 Analyzer. Deep. Res. 37, 157-165. doi: 10.1016/0198-0149(90)90034-S

Vogt, H., and Schramm, W. (1991). Conspicuous decline of Fucus in Kiel Bay (Western Baltic): what are the causes? Mar. Ecol. Prog. Ser. 69, 189-194. doi: 10.3354/meps069189

Wahl, M., Buchholz, B., Winde, V., Golomb, D., Guy-Haim, T., Müller, J., et al. (2015b). A mesocosm concept for the simulation of near-natural shallow underwater climates: the Kiel Outdoor Benthocosms (KOB). Limnol. Oceanogr. Methods. doi: 10.1002/lom3.10055

Wahl, M., Jormalainen, V., Eriksson, B. K., Coyer, J. A., Molis, M., Schubert, H., et al. (2011). "Stress ecology in Fucus: abiotic, biotic and genetic interactions," in Advances in Marine Biology, ed M. Lesser (Oxford: Elsevier Ltd), 37-105.

Wahl, M., Molis, M., Hobday, A. J., Dudgeon, S., Neumann, R., Steinberg, P., et al. (2015a). The responses of brown macroalgae to environmental change from local to global scales: direct versus ecologically mediated effects. Perspect. Phycol. 2, 11-30. doi: 10.1127/pip/2015/0019

Wahl, M., Saderne, V., and Sawall, Y. (2015c). How good are we at assessing the impact of ocean acidification in coastal systems? Limitations, omissions and strengths of commonly used experimental approaches with special emphasis on the neglected role of fluctuations. Mar. Freshw. Res. doi: 10.1071/MF14154. [Epub ahead of print].

Wahl, M., Shahnaz, L., Dobretsov, S., Saha, M., Symanowski, F., David, K., et al. (2010). Ecology of antifouling resistance in the bladder wrack Fucus vesiculosus: patterns of microfouling and antimicrobial protection. Mar. Ecol. Prog. Ser. 411, 33-48. doi: 10.3354/meps08644

Weidner, M., and Ziemens, C. (1975). Preadaptation of protein synthesis in wheat seedlings to high temperature. Plant Physiol. 56, 590-594. doi: $10.1104 /$ pp.56.5.590

Weinberger, F., Buchholz, B., Karez, R., and Wahl, M. (2008). The invasive red alga Gracilaria vermiculophylla in the Baltic Sea: adaptation to brackish water may compensate for light limitation. Aquat. Biol. 3, 251-264. doi: 10.3354/ab00083

Weinberger, F., Rohde, S., Oschmann, Y., Shahnaz, L., Dobretsov, S., and Wahl, M. (2011). Effects of limitation stress and of disruptive stress on induced antigrazing defense in the bladder wrack Fucus vesiculosus. Mar. Ecol. Prog. Ser. 427, 83-94. doi: 10.3354/meps09044

Wernberg, T., Russell, B. D., Thomsen, M. S., Gurgel, C. F. D., Bradshaw, C. J. A., Poloczanska, E. S., et al. (2011). Seaweed communities in retreat from ocean warming. Curr. Biol. 21, 1828-1832. doi: 10.1016/j.cub.2011.09.028

Wernberg, T., Smale, D. A., and Thomsen, M. S. (2012). A decade of climate change experiments on marine organisms: procedures, patterns and problems. Glob. Chang. Biol. 18, 1491-1498. doi: 10.1111/j.1365-2486.2012. 02656.x

Wernberg, T., Thomsen, M. S., Tuya, F., Kendrick, G. A., Staehr, P. A., and Toohey, B. D. (2010). Decreasing resilience of kelp beds along a latitudinal temperature gradient: potential implications for a warmer future. Ecol. Lett. 13, 685-694. doi: $10.1111 /$ j.1461-0248.2010.01466.x 
Werner, F. J., Graiff, A., and Matthiessen, B. (2015). Temperature effects on seaweed-sustaining top-down control vary with season. Oecologia. doi: 10.1007/s00442-015-3489-x. [Epub ahead of print].

Winde, V., Böttcher, M. E., Escher, P., Böning, P., Beck, M., Liebezeit, G., et al. (2014). Tidal and spatial variations of $\mathrm{DI}^{13} \mathrm{C}$ and aquatic chemistry in a temperate tidal basin during winter time. J. Mar. Syst. 129, 396-404. doi: 10.1016/j.jmarsys.2013.08.005

Winters, G., Nelle, P., Fricke, B., Rauch, G., and Reusch, T. (2011). Effects of a simulated heat wave on photophysiology and gene expression of high- and lowlatitude populations of Zostera marina. Mar. Ecol. Prog. Ser. 435, 83-95. doi: 10.3354/meps09213

Woodin, S. A., Hilbish, T. J., Helmuth, B., Jones, S. J., and Wethey, D. S. (2013). Climate change, species distribution models, and physiological performance metrics: predicting when biogeographic models are likely to fail. Ecol. Evol. 3, 3334-3346. doi: 10.1002/ece3.680

Wootton, J. T., Pfister, C. A., and Forester, J. D. (2008). Dynamic patterns and ecological impacts of declining ocean $\mathrm{pH}$ in a high-resolution multiyear dataset. Proc. Natl. Acad. Sci. U. S. A. 105, 18848-18853. doi: 10.1073/pnas.0810079105

Worm, B., and Lotze, H. K. (2006). Effects of eutrophication, grazing, and algal blooms on rocky shores. Limnol. Oceanogr. 51, 569-579. doi: 10.4319/lo.2006.51.1_part_2.0569
$\mathrm{Wu}$, H., Zou, D., and Gao, K. (2008). Impacts of increased atmospheric $\mathrm{CO}_{2}$ concentration on photosynthesis and growth of micro- and macroalgae. Sci. China Ser. C Life Sci. 51, 1144-1150. doi: 10.1007/s11427-0080142-5

Wu, X., Wu, Z., and Song, L. (2011). Phenotype and temperature affect the affinity for dissolved inorganic carbon in a cyanobacterium Microcystis. Hydrobiologia 675, 175-186. doi: 10.1007/s10750-011-0815-0

Zou, D., and Gao, K. (2009). Effects of elevated $\mathrm{CO}_{2}$ on the red seaweed Gracilaria lemaneiformis (Gigartinales, Rhodophyta) grown at different irradiance levels. Phycologia 48, 510-517. doi: 10.2216/08-99.1

Conflict of Interest Statement: The authors declare that the research was conducted in the absence of any commercial or financial relationships that could be construed as a potential conflict of interest.

Copyright (c) 2015 Graiff, Bartsch, Ruth, Wahl and Karsten. This is an openaccess article distributed under the terms of the Creative Commons Attribution License (CC BY). The use, distribution or reproduction in other forums is permitted, provided the original author(s) or licensor are credited and that the original publication in this journal is cited, in accordance with accepted academic practice. No use, distribution or reproduction is permitted which does not comply with these terms. 